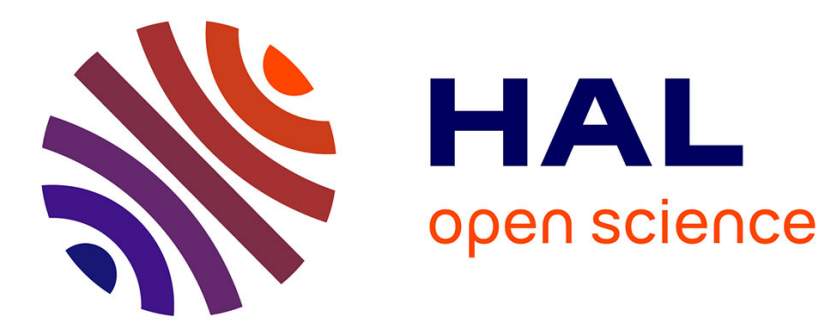

\title{
Light elements, volatiles, and stable isotopes in basaltic melt inclusions from Grenada, Lesser Antilles: Inferences for magma genesis
}

\author{
A.-S. Bouvier, N. Métrich, E. Deloule
}

\section{- To cite this version:}

A.-S. Bouvier, N. Métrich, E. Deloule. Light elements, volatiles, and stable isotopes in basaltic melt inclusions from Grenada, Lesser Antilles: Inferences for magma genesis. Geochemistry, Geophysics, Geosystems, 2010, 11, pp.Q09004. 10.1029/2010GC003051 · hal-00537894

\section{HAL Id: hal-00537894 \\ https://hal.science/hal-00537894}

Submitted on 9 Jun 2017

HAL is a multi-disciplinary open access archive for the deposit and dissemination of scientific research documents, whether they are published or not. The documents may come from teaching and research institutions in France or abroad, or from public or private research centers.
L'archive ouverte pluridisciplinaire HAL, est destinée au dépôt et à la diffusion de documents scientifiques de niveau recherche, publiés ou non, émanant des établissements d'enseignement et de recherche français ou étrangers, des laboratoires publics ou privés. 


\title{
Light elements, volatiles, and stable isotopes in basaltic melt inclusions from Grenada, Lesser Antilles: Inferences for magma genesis
}

\author{
A.-S. Bouvier \\ Centre de Recherche Pétrographiques et Géochimiques, Nancy-Université, CNRS, F-54501 \\ Vandoeuvre-les-Nancy, France \\ Now at SIS2M, CNRS, CE-Saclay, CEA, F-91191 Gif-sur-Yvette CEDEX, France \\ (anne-sophie.bouvier@cnrs-orleans.fr) \\ N. Métrich \\ Institut de Physique du Globe de Paris, CNRS UMR 7154, Université Paris Diderot, \\ Sorbonne Paris-Cité, F-75238 Paris CEDEX 05, France

\section{E. Deloule} \\ Centre de Recherche Pétrographiques et Géochimiques, Nancy-Université, CNRS, F-54501 \\ Vandoeuvre-les-Nancy, France
}

[1] Grenada Island is located at the southern end of the Lesser Antilles. Grenada lavas display a large range in compositions which includes picrites, representing the parental melt of all Grenada suites. We present here an extensive study of major, light and volatile elements combined with $\delta \mathrm{D}, \delta^{11} \mathrm{~B}$ and $\delta^{7} \mathrm{Li}$ determinations of melt inclusions hosted in olivines $\left(\mathrm{Fo}_{86-91}\right)$ from picritic scoriae. The major element compositions of melt inclusions encompass those of Grenada basalts. Their $\mathrm{H}_{2} \mathrm{O}$ contents typically range from 0.2 to $4.1 \mathrm{wt} \%$ (one value at $6.4 \mathrm{wt} \%$ ). Such extreme range stands in contrast with typical arc magmas for a single volcanic center. The high $\mathrm{H}_{2} \mathrm{O}$ contents are associated with strongly negative values of $\delta \mathrm{D}$ (on average $-140 \%$ ). Melt inclusions display a wide range in $\mathrm{B}(1.7-47 \mathrm{ppm})$ and $\mathrm{Li}(1.1-12 \mathrm{ppm})$ contents as well as in $\delta^{7} \mathrm{Li}$ and $\delta^{11} \mathrm{~B}$, which vary from -24 to $8.2 \%$ and from -20 to $8.9 \%$, respectively. Both $\mathrm{B}$ and $\mathrm{Li}$ compositions of Grenada melt inclusions suggest (i) the involvement of dehydration fluids or hydrous silicate melts derived from buried carbonate-bearing sediments, (ii) the contribution of aqueous fluids generated during the dehydration of hydrothermally altered oceanic crust, and (iii) melting of a mantle metasomatized by the addition of high $\delta^{11} \mathrm{~B}$, high-Cl, Li-poor fluids derived from the early dehydration of serpentinized peridotite above the slab beneath Grenada.

Components: 14,400 words, 8 figures, 6 tables.

Keywords: Lesser Antilles arc; subduction; melt inclusions; picrites; volatiles; stable isotopes.

Index Terms: 3613 Mineralogy and Petrology: Subduction zone processes (1031, 3060, 8170, 8413).

Received 19 January 2010; Revised 14 June 2010; Accepted 1 July 2010; Published 8 September 2010.

Bouvier, A.-S., N. Métrich, and E. Deloule (2010), Light elements, volatiles, and stable isotopes in basaltic melt inclusions from Grenada, Lesser Antilles: Inferences for magma genesis, Geochem. Geophys. Geosyst., 11, Q09004, doi:10.1029/2010GC003051. 


\section{Introduction}

[2] The volcanism of Grenada, the southernmost island of the Lesser Antilles arc (Figure 1), is exceptional for providing (i) an unusual variety of magmas ranging from picrites and high-MgO basalts (M-series) to calcic, clinopyroxene megaphyric lavas (C-series) [Devine, 1995; Hawkesworth et al., 1979; Thirlwall and Graham, 1984], and (ii) ultramafic mantle xenoliths (harzburgite, dunite, lherzolite and subordinate werlhite and pyroxenite) carried by alkali olivine basalts that testify to multistage sub-arc mantle-melt reactions [Parkinson et al., 2003; Vannucci et al., 2007]. Moreover, Grenada is located in proximity of the major transform bounding fault between the Caribbean plate and the South American continental platform, creating a peculiar geological context.

[3] Picrites ( $>11 \mathrm{wt} \% \mathrm{MgO})$, uncommon in arc settings, are abundant in Grenada [Arculus, 1976; Thirlwall et al., 1996] and have been found to be unaffected [Devine, 1995; White and Dupré, 1986], or only slightly affected [Thirlwall et al., 1996] by high level crustal interactions. These magmas have compositions matching those produced by experimental batch melting (16-40\% partial melting) of anhydrous mantle peridotite at pressures of 1530 kbar, $1350-1500^{\circ} \mathrm{C}$ [Hirose and Kushiro, 1993]. This may imply that picritic melts were last in equilibrium with the mantle at $\sim 65 \mathrm{~km}$ depth, and could thus have been rapidly brought to the surface [Devine, 1995]. It has been suggested that this rapid magma ascent may be favored by the major tectonic SW-NE fault crossing Grenada [Devine, 1995; Van Soest et al., 2002]. Picritic melts have been regarded as the parental magmas of Grenada lava series [Devine, 1995], and are, with the M-series basalts, the least differentiated Lesser Antilles arc lavas [Devine, 1995; Macdonald et al., 2000; Thirlwall et al., 1996]. These high$\mathrm{MgO}$ rocks are thus suitable candidates for retrieving the volatile abundances in Grenada primary melts and evaluating the influence of slabcomponents in their geochemistry.

[4] There is a consensus that $\mathrm{M}$-series magmas $(\mathrm{MgO}$ from 11 to $16 \mathrm{wt} \%)$ are generated by variable extents of melting of a MORB-type mantle source modified by the contributions of hydrous fluids and a sediment component [Devine, 1995; Macdonald et al., 2000; Thirlwall et al., 1996]. Compared to other Lesser Antilles arc suites,
$\mathrm{M}$-series lavas are thought to record the largest contribution of the sediment-derived slab component [Macdonald et al., 2000], estimated to range from 0.4 to $3 \%$ [White and Dupré, 1986], and possibly up to $15 \%$ [Turner et al., 1996], based on $\mathrm{Hf}, \mathrm{Nd}, \mathrm{Sr}$ isotopes and U-series isotopes measured on lavas, respectively. Grenada lavas have radiogenic $\mathrm{Pb}$ isotopic compositions, as do those of St. Vincent and the Grenadines, which achieve higher values than those found in lavas from other arc settings [e.g., Carpentier et al., 2008; Turner et al., 1996; White and Dupré, 1986]. Radiogenic $\mathrm{Pb}$ ratios were ascribed to either crustal contamination [Thirlwall et al., 1996] or sediment input from the mantle wedge [Macdonald et al., 2000; Turner et al., 1996; White and Dupré, 1986]. More recently, it has been proposed that variability of $\mathrm{Pb}$ isotopes and high ${ }^{206} \mathrm{~Pb} /{ }^{204} \mathrm{~Pb}$ ratios observed in lavas from the southernmost islands of the Lesser Antilles arc may be partly due to the subduction of black shales $\left({ }^{206} \mathrm{~Pb} /{ }^{204} \mathrm{~Pb}\right.$ up to 27.69$)$, present in the accretionary prism near Barbados (DSPD Leg 144, [Carpentier et al., 2008]). The nature and the contribution of each component are still under debate [Macdonald et al., 2000; Van Soest et al., 2002].

[5] The present study aims to better constrain the volatile and light element initial contents of these primitive magmas by chemical and isotopic analysis of the basaltic to picritic melt inclusions (MIs) entrapped in high-MgO olivine. This should permit a better understanding of the nature and the relative proportions of the different fluids that have affected their source. We combine measurements of light and mobile elements content $\left(\mathrm{H}_{2} \mathrm{O}, \mathrm{Li}, \mathrm{B}, \mathrm{Cl}\right)$ and their isotopic compositions $\left(\delta^{7} \mathrm{Li}, \delta^{11} \mathrm{~B}, \delta \mathrm{D}\right)$ to quantify the fluid contributions [Chan et al., 1992, 1993, 1994; Huh et al., 2001; Ishikawa and Nakamura, 1993; Peacock and Hervig, 1999; Rudnick et al., 2004; Ryan and Langmuir, 1993; Spivack and Edmond, 1987; Stoffyn-Egli and Mackenzie, 1984; Straub and Layne, 2003b; Teng et al., 2004; Wunder et al., 2005].

[6] The chemical and isotopic compositions of the MIs span a larger range of compositions than that of Grenada M-series lavas. These minute fractions of melt entrapped during crystal growth record small scale heterogeneities which can be strongly attenuated or even lost in bulk rocks [e.g., Sobolev and Shimizu, 1993]. Here we explore the different processes that may explain the dominantly low 


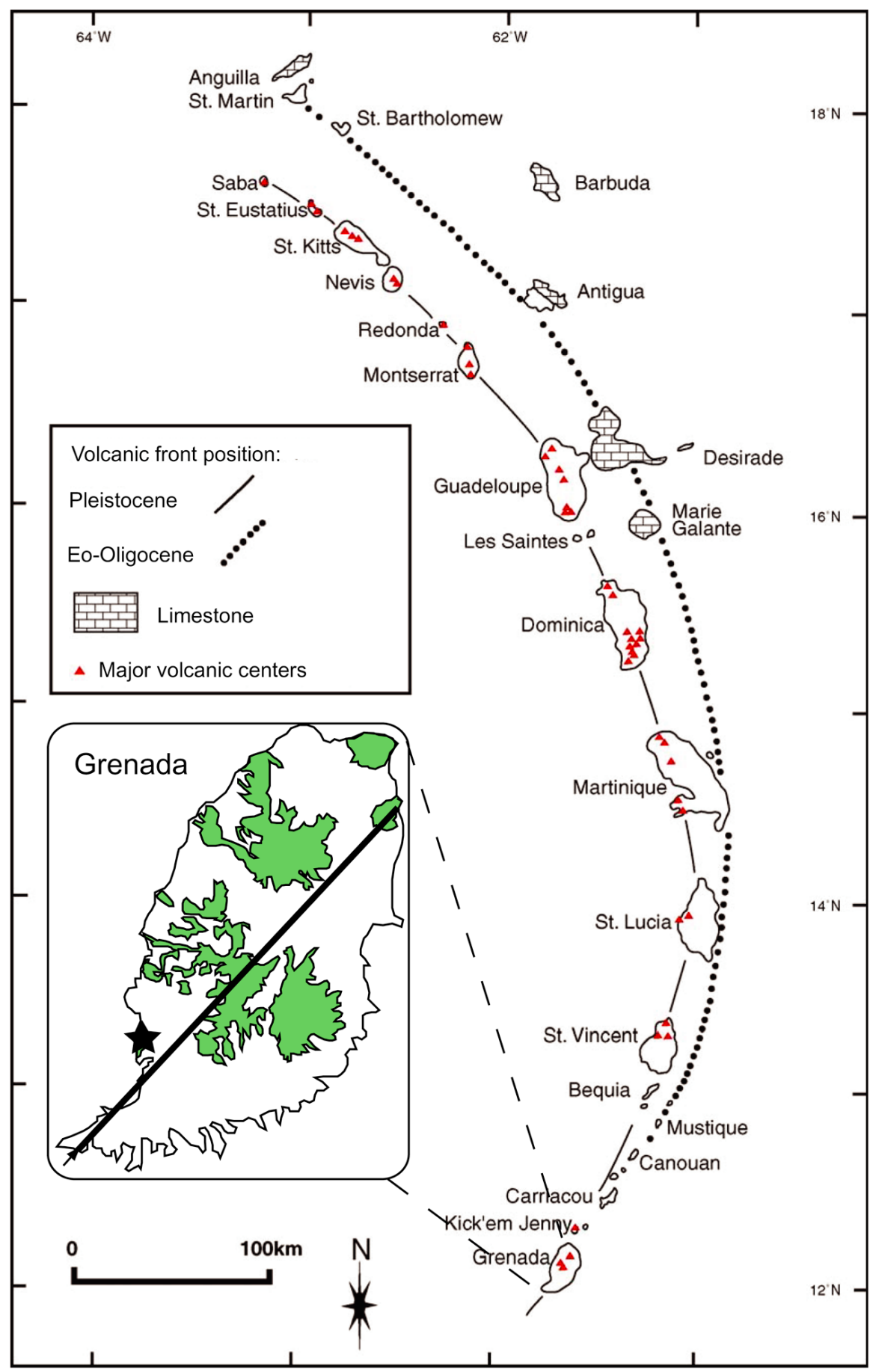

Figure 1. Map of the Lesser Antilles arc (modified from Poussineau [2005]). The inset of Grenada Island shows the major volcanic centers in green (modified from Arculus [1976] and Devine [1995]) and the Queen's Park location (star), where the studied scoriae were sampled. 
$\mathrm{H}_{2} \mathrm{O}$ concentrations in MIs, and discuss their B and $\mathrm{Li}$ chemical and isotopic variations in relation to distinct slab-derived fluids.

\section{Sample Location and Description}

[7] A systematic sampling of basaltic scoriae and lapilli was conducted in Grenada to collect quenched magma products suitable for MI analysis. Most MIs were found to be crystallized, as previously reported for the Lesser Antilles arc [Bouvier et al., 2008; Devine, 1995], except those from the explosive products of Queen's Park scoria cone, in the southwest part of the island (Figure 1). The scoria deposits were sampled from the base (G05-06) to the top (G05-08) of the cone, where fragments of tectonized mantle xenoliths are ubiquitous [Devine, 1995]. The lava and scoria contain dominantly olivine and pyroxene phenocrysts whereas plagioclase occurs in the groundmass only. Magmatic olivines are euhedral to polyhedral, whereas olivine xenocrysts resulting from the breakup of mantle xenoliths are often fragmented, and occasionally display kink bands.

[8] More than 500 olivines from 3 layers (G05-06, 07, 08) of Queen's Park cone were hand-picked under microscope from a 0.5 to $1 \mathrm{~mm}$ grain size fraction of gently crushed scoriae. Olivines containing MIs were individually polished to expose their MIs at the surface. Three samples of lava and scoria from Queen's Park cone were analyzed for major elements (Table 1). The results are similar to those previously reported [Devine, 1995].

\section{Analytical Methods}

[9] Bulk rocks were analyzed for major elements at the SARM laboratory (CRPG, Nancy) by ICP-AES (Table 1). Major elements were measured in MIs, olivines and spinels using a CAMECA SX50 electron microprobe (CAMPARIS, Paris), with the analytical conditions detailed by Bouvier et al. [2008]: $40 \mathrm{nA}$ focused beam and $200 \mathrm{~s}$ counting time for olivine and spinel analyses, and $10 \mathrm{nA}$ defocused beam, 10-15 s (up to $40 \mathrm{~s}$ for $\mathrm{K}_{2} \mathrm{O}$ ) counting time for MI major elements. Each MI analysis quoted in Table 2 is the average of 3 measured points.

[10] Light trace elements $(\mathrm{Li}, \mathrm{B})$, volatiles $\left(\mathrm{H}_{2} \mathrm{O}\right.$, $\mathrm{Cl}, \mathrm{S})$ and isotopic ratios $\left(\delta^{7} \mathrm{Li}, \delta^{11} \mathrm{~B}\right)$ were analyzed using the CAMECA IMS 1270 of CRPG (Nancy, France), with a primary beam current of
Table 1. Major Element Compositions of Queen's Park Bulk Rocks

\begin{tabular}{|c|c|c|c|c|}
\hline & $\begin{array}{c}\text { G05-0 } 7^{\mathrm{a}} \text { : } \\
\text { Scoria }\end{array}$ & $\begin{array}{c}\text { G } 05-10^{\mathrm{b}}: \\
\text { Lava }\end{array}$ & $\begin{array}{c}\text { G05-1 } 1^{\mathrm{a}}: \\
\text { Lava }\end{array}$ & $\begin{array}{r}\text { GDA008 } \\
\text { Scoria }\end{array}$ \\
\hline $\mathrm{SiO}_{2}$ & 46.41 & 47.70 & 45.99 & 46.88 \\
\hline $\mathrm{TiO}_{2}$ & 0.85 & 0.82 & 0.83 & 0.8 \\
\hline $\mathrm{Al}_{2} \mathrm{O}_{3}$ & 14.20 & 13.35 & 13.64 & 13.81 \\
\hline $\mathrm{Fe}_{2} \mathrm{O}_{3}$ & 9.81 & 9.60 & 10.10 & 8.81 \\
\hline $\mathrm{MnO}$ & 0.17 & 0.16 & 0.17 & 0.16 \\
\hline $\mathrm{MgO}$ & 14.51 & 14.00 & 16.18 & 15.7 \\
\hline $\mathrm{CaO}$ & 10.94 & 11.80 & 10.72 & 10.48 \\
\hline $\mathrm{Na}_{2} \mathrm{O}$ & 1.98 & 2.08 & 2.02 & 1.81 \\
\hline $\mathrm{K}_{2} \mathrm{O}$ & 0.47 & 0.48 & 0.44 & 0.42 \\
\hline $\mathrm{P}_{2} \mathrm{O}_{5}$ & 0.16 & 0.14 & 0.14 & 0.27 \\
\hline L.O.I. $^{\mathrm{d}}$ & 0.42 & -0.06 & -0.02 & 0.41 \\
\hline Total & 99.92 & 100.07 & 100.22 & 99.32 \\
\hline
\end{tabular}

${ }^{\mathrm{a}}$ This study.

${ }^{\mathrm{b}}$ Analysis from L. Wulput (Brest, France).

${ }^{\mathrm{c}}$ Devine [1995].

${ }^{\mathrm{d}}$ L.O.I.: loss on ignition.

$10-15 \mathrm{nA}$ and $\sim 10 \mu \mathrm{m}$ projected beam size. Analytical methods and standards used are described by Bouvier et al. [2008].

[11] $\mathrm{H}_{2} \mathrm{O}, \mathrm{Li}, \mathrm{B}, \delta^{7} \mathrm{Li}$ and $\delta^{11} \mathrm{~B}$ SIMS analyses were performed with an $\mathrm{O}^{-}$primary beam. The $\mathrm{H}_{2} \mathrm{O}$, Li and $\mathrm{B}$ contents were measured in a single analysis, with a mass resolution of 1200 and energy offset of $-60 \mathrm{~V}$. Intensities of ${ }^{1} \mathrm{H}^{+},{ }^{7} \mathrm{Li}^{+},{ }^{11} \mathrm{~B}^{+},{ }^{30} \mathrm{Si}^{+}$were measured by peak switching, in monocollection ion counting mode. For $\delta^{7} \mathrm{Li}$ and $\delta^{11} \mathrm{~B}$ measurements, ${ }^{6} \mathrm{Li},{ }^{7} \mathrm{Li},{ }^{10} \mathrm{~B}$ and ${ }^{11} \mathrm{~B}$ were analyzed at a mass resolution of 1500 and without energy offset during 18 min (15 cycles).

[12] $\mathrm{Cl}$ and $\mathrm{S}$ contents were analyzed by SIMS with a $\mathrm{Cs}^{+}$primary beam. ${ }^{32} \mathrm{~S}^{-},{ }^{35} \mathrm{Cl}^{-}$and ${ }^{30} \mathrm{Si}^{-}$were measured in a single analysis in monocollection mode, during a 15 cycle analysis, at 3000 mass resolution and without energy offset.

[13] $\mathrm{H}, \mathrm{Li}, \mathrm{B}, \mathrm{Cl}$ and $\mathrm{S}$ were normalized to $\mathrm{Si}$, and their ionization yields relative to Si determined by measuring international or laboratory standards. The 1SD uncertainties defined on the different standards are as follow: $8 \%$ on $\mathrm{H}_{2} \mathrm{O}, 2 \%$ on $\mathrm{Li}, 4 \%$ on $\mathrm{B}, 6 \%$ on $\mathrm{Cl}, 3 \%$ on $\mathrm{S}$, and $1.2 \%$ on $\delta^{7} \mathrm{Li}, 2.1 \%$ on $\delta^{11} \mathrm{~B}$. The average sample reproducibilities (1SD) were $15 \%$ for $\mathrm{H}_{2} \mathrm{O}, 16 \%$ for $\mathrm{Li}, 8 \%$ for $\mathrm{B}$, $14 \%$ for $\mathrm{Cl}, 12 \%$ for $\mathrm{S}, 1.3 \%$ for $\delta^{7} \mathrm{Li}, 2.2 \%$ for $\delta^{11} \mathrm{~B}$.

[14] $\delta \mathrm{D}$ measurements were performed on the same set of MIs after slight repolishing, using the CRPG CAMECA IMS $3 \mathrm{f}$ with a $10 \mathrm{kV}, 10 \mathrm{nA} \mathrm{O}^{-}$primary beam, a $20 \mu \mathrm{m}$ beam size. $\mathrm{H}^{+}, \mathrm{H}_{2}^{+}$and $\mathrm{D}^{+}$were measured by peak switching in mono-collection ion counting mode during 100 cycles. The mass 
Table 2 (Sample). Major and Light Trace Elements and Isotopic Compositions of M.I. Analyzed by SIMS ${ }^{\mathrm{a}}$ [The full Table 2 is available in the HTML version of this article]

\begin{tabular}{|c|c|c|c|c|c|c|c|c|c|}
\hline & $\mathrm{G} 05-5 \mathrm{a}^{\mathrm{b}}$ & $\mathrm{G} 05-7 \mathrm{a}^{\mathrm{b}}$ & G05-9 & $\mathrm{G} 05-11 \mathrm{a}^{\mathrm{b}}$ & G05-12 & G05-13a & G05-13c ${ }^{b}$ & G05-13 $g^{b}$ & G05-14 \\
\hline \multicolumn{10}{|c|}{ Measured Compositions } \\
\hline $\mathrm{SiO}_{2}$ & 48.45 & 44.23 & 45.64 & 46.23 & 45.10 & 46.05 & 49.80 & 49.13 & 45.24 \\
\hline $\mathrm{TiO}_{2}$ & 1.11 & 1.17 & 1.09 & 1.12 & 1.04 & 1.13 & 1.07 & 0.82 & 1.02 \\
\hline $\mathrm{Al}_{2} \mathrm{O}_{3}$ & 18.08 & 18.51 & 17.40 & 18.69 & 16.71 & 19.15 & 18.44 & 24.17 & 18.31 \\
\hline $\mathrm{FeO}_{\text {tot }}{ }^{\mathrm{c}}$ & 7.69 & 9.38 & 8.73 & 8.71 & 8.75 & 7.79 & 7.08 & 6.50 & 8.36 \\
\hline $\mathrm{MnO}$ & 0.11 & 0.14 & 0.14 & 0.09 & 0.19 & 0.15 & 0.09 & 0.13 & 0.08 \\
\hline $\mathrm{MgO}$ & 6.18 & 6.32 & 5.39 & 5.19 & 5.91 & 5.71 & 5.28 & 2.06 & 4.73 \\
\hline $\mathrm{CaO}$ & 13.12 & 13.84 & 14.51 & 12.77 & 13.14 & 13.63 & 12.53 & 12.83 & 15.52 \\
\hline $\mathrm{Na}_{2} \mathrm{O}$ & 3.10 & 3.01 & 3.63 & 3.78 & 2.42 & 3.26 & 3.50 & 3.33 & 1.51 \\
\hline $\mathrm{K}_{2} \mathrm{O}$ & 0.71 & 0.66 & 0.71 & 0.95 & 0.55 & 0.68 & 0.73 & 0.66 & 0.62 \\
\hline Total & 98.55 & 97.25 & 97.24 & 97.53 & 93.81 & 97.55 & 98.51 & 99.64 & 95.39 \\
\hline $\mathrm{CaO} / \mathrm{Al}_{2} \mathrm{O}_{3}$ & 0.73 & 0.75 & 0.83 & 0.68 & 0.79 & 0.71 & 0.68 & 0.53 & 0.85 \\
\hline \multicolumn{10}{|c|}{ Corrected Compositions (Anhydrous) } \\
\hline $\mathrm{SiO}_{2}$ & 48.92 & 45.23 & 46.14 & 46.79 & 47.91 & 46.76 & 50.16 & 48.09 & 45.47 \\
\hline $\mathrm{TiO}_{2}$ & 1.10 & 1.15 & 1.02 & 1.05 & 1.07 & 1.09 & 1.05 & 0.72 & 1.01 \\
\hline $\mathrm{Al}_{2} \mathrm{O}_{3}$ & 17.84 & 18.15 & 16.25 & 17.59 & 17.38 & 18.52 & 18.01 & 21.30 & 17.70 \\
\hline $\mathrm{Fe}_{2} \mathrm{O}_{3}$ & 1.93 & 2.43 & 2.48 & 2.34 & 2.20 & 2.93 & 1.79 & 1.68 & 1.29 \\
\hline $\mathrm{FeO}$ & 6.00 & 7.40 & 6.93 & 7.02 & 7.06 & 5.39 & 5.62 & 6.24 & 7.30 \\
\hline $\mathrm{MnO}$ & 0.11 & 0.14 & 0.13 & 0.09 & 0.18 & 0.15 & 0.09 & 0.12 & 0.08 \\
\hline $\mathrm{MgO}$ & 7.40 & 8.34 & 9.44 & 8.66 & 7.96 & 8.16 & 6.93 & 7.03 & 10.15 \\
\hline $\mathrm{CaO}$ & 12.95 & 13.57 & 13.55 & 12.02 & 13.27 & 13.18 & 12.24 & 11.31 & 14.95 \\
\hline $\mathrm{Na}_{2} \mathrm{O}$ & 3.06 & 2.95 & 3.39 & 3.56 & 2.40 & 3.15 & 3.42 & 2.93 & 1.45 \\
\hline $\mathrm{K}_{2} \mathrm{O}$ & 0.70 & 0.65 & 0.66 & 0.89 & 0.58 & 0.66 & 0.71 & 0.58 & 0.60 \\
\hline $\mathrm{PEC} \%{ }^{\mathrm{d}}$ & 2.8 & 4.6 & 9.4 & 8.2 & 4.4 & 11.6 & 3.8 & 12.2 & 13.7 \\
\hline \multicolumn{10}{|c|}{ Host Olivine Compositions } \\
\hline $\mathrm{SiO}_{2}$ & 40.12 & 40.28 & 40.66 & 41.22 & 41.30 & 41.26 & 40.67 & 40.36 & 41.38 \\
\hline $\mathrm{MgO}$ & 48.33 & 46.66 & 48.58 & 48.21 & 48.16 & 49.10 & 48.46 & 47.12 & 47.29 \\
\hline $\mathrm{CaO}$ & 0.14 & 0.13 & 0.15 & 0.16 & 0.16 & 0.14 & 0.15 & 0.20 & 0.10 \\
\hline $\mathrm{NiO}$ & 0.39 & 0.35 & 0.36 & 0.26 & 0.26 & 0.28 & 0.28 & 0.22 & 0.26 \\
\hline $\mathrm{FeO}$ & 9.50 & 11.83 & 10.08 & 10.80 & 11.77 & 9.93 & 11.12 & 11.86 & 9.80 \\
\hline $\mathrm{MnO}$ & 0.15 & 0.18 & 0.15 & 0.18 & 0.19 & 0.14 & 0.18 & 0.19 & 0.17 \\
\hline Fo $\%$ & 88.0 & 87.5 & 89.6 & 88.8 & 87.9 & 89.8 & 88.6 & 87.6 & 89.6 \\
\hline Total & 98.6 & 99.4 & 100.0 & 100.8 & 101.8 & 100.9 & 100.9 & 100.0 & 99.0 \\
\hline \multicolumn{10}{|c|}{ SIMS Data } \\
\hline $\mathrm{H}_{2} \mathrm{O}^{\mathrm{f}}(\mathrm{wt} \%)$ & 0.48 & 1.67 & 0.97 & 0.48 & 3.62 & 2.48 & 0.39 & 0.48 & 1.85 \\
\hline $\mathrm{Li}^{\mathrm{f}}(\mathrm{ppm})$ & 5.82 & 5.99 & 19.22 & 9.71 & 4.40 & 6.51 & 3.18 & 6.24 & 4.25 \\
\hline $\mathrm{B}^{\mathrm{f}}(\mathrm{ppm})$ & 19.48 & 9.96 & 6.98 & 11.76 & 7.09 & 15.89 & 1.89 & 8.54 & 9.87 \\
\hline $\mathrm{F}^{\mathrm{f}}(\mathrm{ppm})$ & 1298 & 583 & 665 & 421 & 349 & n.d. & n.d. & n.d. & 365 \\
\hline$S^{f}(p p m)$ & n.d. & 1029 & 978 & 1261 & 235 & n.d. & n.d. & n.d. & 2475 \\
\hline $\mathrm{Cl}^{\mathrm{f}}(\mathrm{ppm})$ & 2078 & 2041 & 1896 & 2593 & 1103 & n.d. & n.d. & n.d. & 2582 \\
\hline$\delta^{7} \mathrm{Li}^{\mathrm{f}}(\% \mathrm{o})$ & -6.22 & n.d. & -0.30 & 3.64 & 7.27 & 6.17 & 7.43 & 4.51 & 7.03 \\
\hline$\delta^{11} \mathrm{~B}^{\mathrm{f}}(\% \mathrm{o})$ & -19.58 & 0.81 & 2.20 & -6.53 & 0.43 & -9.74 & -5.84 & 2.84 & -4.99 \\
\hline$\delta^{18} \mathrm{O}^{\mathrm{f}}(\% \mathrm{o})$ & 6.10 & 8.20 & 5.30 & 9.00 & 6.50 & n.d. & n.d. & n.d. & 11.40 \\
\hline$\delta \mathrm{D}^{\mathrm{g}}(\% \mathrm{o})$ & n.d. & n.d. & n.d. & n.d. & n.d. & n.d. & n.d. & n.d. & n.d. \\
\hline
\end{tabular}

${ }^{a}$ n.d.: not determined. Some melt inclusions, as $\mathrm{G} 05-12,14,73,46 \mathrm{~b}$ have low total, even including volatiles contents. It could be due to $\mathrm{SiO}_{2}$ under-estimation.

b"a, b..." refer to different M.I. in the same crystal and "g" to glass embayments either in contact or not with their surroundings.

${ }^{\mathrm{c}}$ Total $\mathrm{Fe}$ content expressed as $\mathrm{FeO}$ tot; $\mathrm{Fe}_{2} \mathrm{O}_{3}$ is calculated for $15 \%$ of $\mathrm{FeO}_{\text {tot }}$.

${ }^{\mathrm{d}}$ Post-entrapment crystallisation calculated with Petrolog Software [Danyushevsky et al., 2000] at NNO+0.3, using olivine composition close to M.I.

${ }^{e} \mathrm{Fo}=100 \times\left[\mathrm{Mg} /\left(\mathrm{Mg}+\mathrm{Fe}^{2+}\right)\right]$.

${ }^{\mathrm{f}}$ Data measured by CAMECA IMS 1270.

${ }^{g}$ Data measured by CAMECA IMS $3 \mathrm{f}$. 


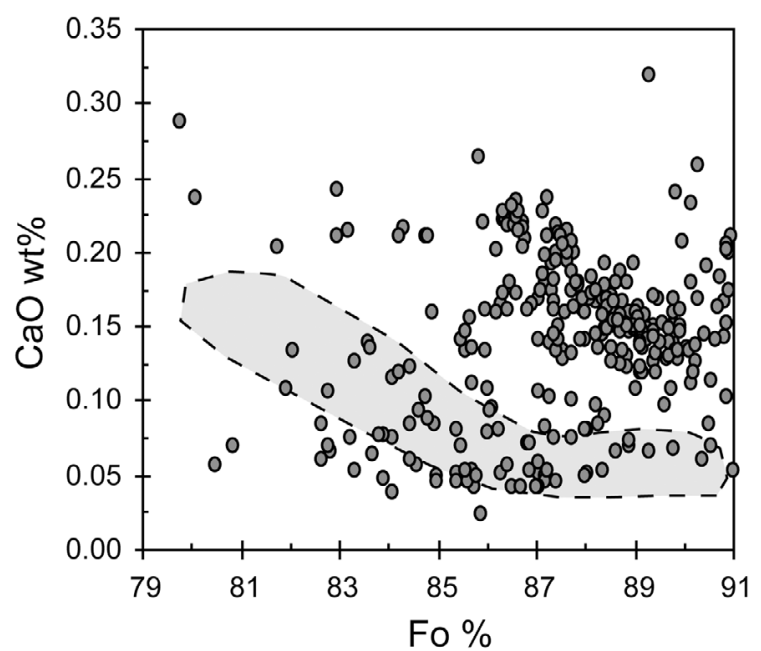

Figure 2. Variations of $\mathrm{CaO}$ versus $\mathrm{Fo} \mathrm{mol} \%$ in Grenada olivines. Each point represents a single spot analysis. Field in gray represents olivine data from Grenada mantle xenoliths [Parkinson et al., 2003].

resolution was set to 1300 to separate $\mathrm{D}$ and $\mathrm{H}_{2}$ [Deloule et al., 1991]. The instrumental fractionation was determined with experimental basaltic glasses (ETNA series) equilibrated at high pressure and temperature $\left(2 \mathrm{kbar}\right.$ and $\left.1150^{\circ} \mathrm{C}\right)$ at ISTO (Orleans, France), with water contents from 1.27 to $2.47 \mathrm{wt} \%$ and $\delta \mathrm{D}$ values from -181 to $-158 \%$ (Table A1) and a MORB glass (CY-82-29-3V), containing $0.19 \mathrm{wt} \%$ of $\mathrm{H}_{2} \mathrm{O}$ with a $\delta \mathrm{D}$ value of $-80 \%$ [Chaussidon et al., 1991]. These standards were used because of their basaltic compositions, similar to those of MIs, in order to avoid any matrix effect. The standard deviation (1SD) is $\pm 8 \%$.

[15] $\mathrm{Li}$ isotopic compositions are reported against reference standard values, as $\delta^{7} \mathrm{Li}=\left[\left({ }^{7} \mathrm{Li} /{ }^{6} \mathrm{Li}\right)_{\text {sample }}-\right.$ $\left.\left.\left.\left({ }^{7} \mathrm{Li} /{ }^{6} \mathrm{Li}\right)_{\text {std }}\right)\right) /\left({ }^{7} \mathrm{Li} /{ }^{6} \mathrm{Li}\right)_{\text {std }}\right] \times 1000$ using $\mathrm{L}$-SVEC standard $\left({ }^{7} \mathrm{Li} /{ }^{6} \mathrm{Li}=12.175\right)$. The same calculation is applied for the other isotopic compositions; $\delta^{11} \mathrm{~B}$ is referenced to NBS $951{ }^{11} \mathrm{~B} /{ }^{10} \mathrm{~B}(4.044)$ and $\delta \mathrm{D}$ to $\mathrm{SMOW}\left(\mathrm{D} / \mathrm{H}: 1.5576 \times 10^{-4}\right)$.

\section{Mineral Chemistry}

[16] Olivines show a large range in chemical compositions, from $\mathrm{Fo}_{91.5}$ to $\mathrm{Fo}_{79.8}$ (Figure 2 and Table 2). Most are normally zoned from $\mathrm{Fo}_{86.3-91.1}$ cores to $\mathrm{Fo}_{78.9-89.7}$ rims. Their $\mathrm{CaO}$ contents vary from 0.10 to $0.22 \mathrm{wt} \%$, except in a few rims $(\mathrm{CaO}$ up to $0.32 \mathrm{wt} \%$; Figure 2), and are negatively correlated with the olivine Fo content, as generally observed during magmatic evolution [e.g., Kamenetsky et al., 2006]. Another population $\left(\mathrm{Fo}_{91-80}\right)$ with low $\mathrm{CaO}(<0.1 \mathrm{wt} \%)$ contents have compositions similar to olivines from Grenada mantle xenoliths [Parkinson et al., 2003; Vannucci et al., 2007]. These olivine xenocrysts do not contain MIs; they are ubiquitous and clearly inherited from disaggregated mantle xenoliths as previously reported [Devine, 1995]. We found some "composite olivines" with typical magmatic overgrowths on mantle-xenolith olivine cores. Abrupt core-rim transition, commonly marked by the presence of spinels, indicates no significant element diffusion between olivine core and rim.

[17] We focus here on magmatic olivines. These olivines contain MIs and numerous $\mathrm{Cr}$-spinels with $\mathrm{Cr} \#[\mathrm{Cr} /(\mathrm{Cr}+\mathrm{Al})]$ varying from 0.36 to 0.70 and $\mathrm{Mg} \#[\mathrm{Mg} /(\mathrm{Mg}+\mathrm{Al})]$ from 0.30 to 0.66 (Table A2). These values overlap in composition with spinels from Grenada xenoliths [Parkinson et al., 2003]. The olivine-spinel pairs have lower Mg\# than abyssal peridotites from various settings (Figure 3), which has been suggested, combined with petrographic observations, to reflect mantle/melt interactions [Parkinson et al., 2003].

\section{Melt Inclusions}

\subsection{Major Element Chemistry}

[18] The selected MIs are preserved as glass and range in size from $<10$ to $\sim 60 \mu \mathrm{m}$, with a few up

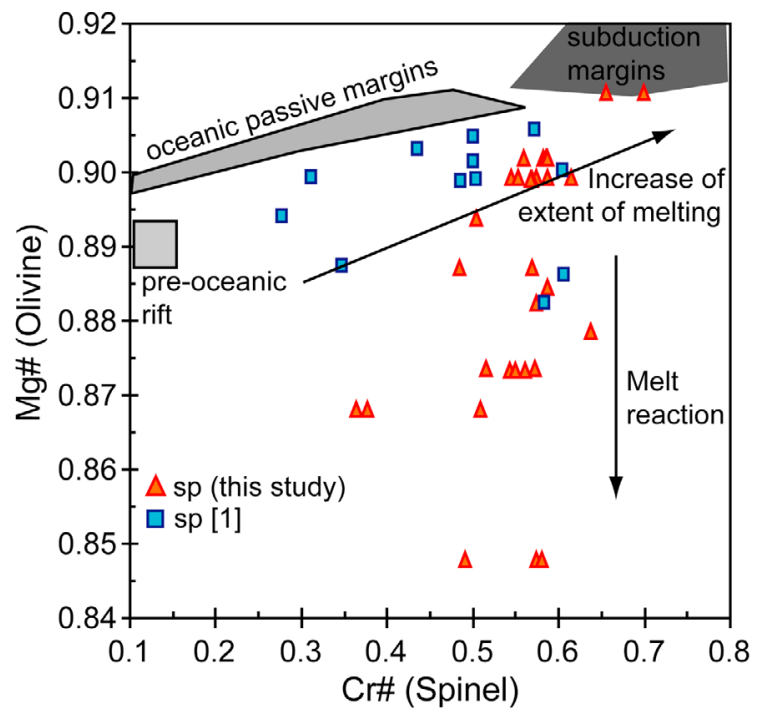

Figure 3. Spinel Cr\# versus olivine Mg\#, modified from Parkinson et al. [2003]. Spinel compositions from this study are reported in Table A2. Compositions of spinels and their associated olivines of Grenada xenoliths (indicated by [1]) are from Parkinson et al. [2003] and fields of pre-rift, oceanic and subduction peridotites from Bonatti and Michael [1989]. 

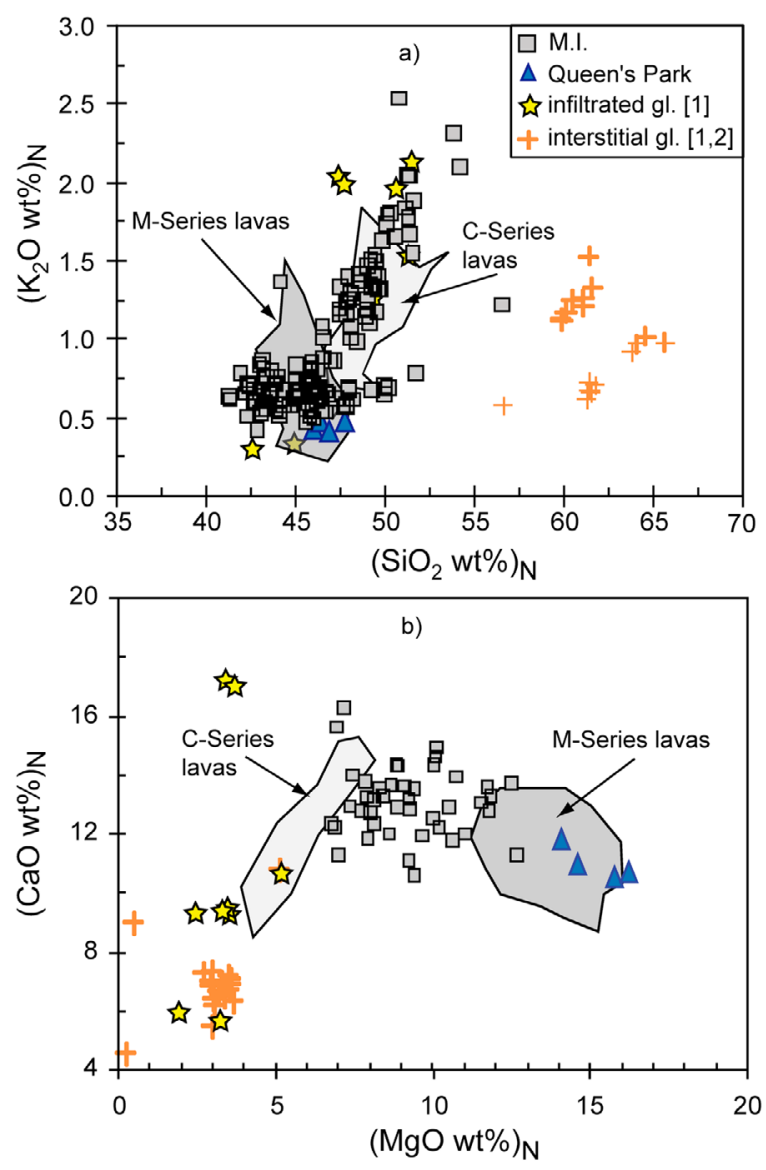

Figure 4. Variations of (a) $\mathrm{K}_{2} \mathrm{O}$ versus $\mathrm{SiO}_{2}$ and (b) $\mathrm{CaO}$ versus $\mathrm{MgO}$ in Grenada olivine-hosted MIs and embayments. Compositions of lavas and scoriae of Queen's Park are from this work (Table 1) and Devine [1995]. The dark and light gray fields represent bulk compositions of $\mathrm{M}$ - and C-Series lavas, respectively [Devine, 1995; Thirlwall et al., 1994, 1996; Turner et al., 1996; Van Soest et al., 2002; Woodland et al., 2002]. Compositions of infiltrated ([1] = Vannucci et al. [2007]) and interstitial $([1,2]=$ Vannucci et al. [2007] and Parkinson et al. [2003]) glasses in xenoliths are plotted for comparison. In Figure $4 \mathrm{~b}$ only MIs selected for ion probe measurements are plotted. They fill the gap between the Grenada $\mathrm{M}$-series and $\mathrm{C}$-series lava fields.

to $\sim 100 \mu \mathrm{m}$. They are commonly ovoid, with a shrinkage bubble, no sulphide globules, and are sometimes associated with a spinel. The smallest MIs $(<20 \mu \mathrm{m})$, which are abundant, were not analyzed to avoid any possible bias related to boundary layer effects [Anderson, 1974; Kuzmin and Sobolev, 2003]. Among the 113 MIs analyzed for major elements, more than half are included in euhedral magmatic crystals $\left(\mathrm{Fo}_{86-91}\right)$; the remaining MIs are trapped in magmatic overgrowths.

[19] Melt inclusions display a broad spectrum in major elements contents (Figures $4 \mathrm{a}$ and $4 \mathrm{~b}$ ), with no distinction between melt entrapped in euhedral magmatic olivines and in overgrowths. We observe two trends in the major element chemistry of the MIs. The co-variation of $\mathrm{SiO}_{2}(>48 \mathrm{wt} \%)$ and $\mathrm{K}_{2} \mathrm{O}$ $(>0.9 \mathrm{wt} \%)$ contents as the $\mathrm{CaO} / \mathrm{Al}_{2} \mathrm{O}_{3}$ ratio decreases (from 0.74 to 0.43 ) matches the $\mathrm{C}$-series trend. The latter was proposed to result either from crystal fractionation and removal of an assemblage composed of olivine, pyroxene, and amphibole \pm plagioclase [Devine, 1995] or from interactions between low $\mathrm{SiO}_{2}$-melt, similar to $\mathrm{M}$-series magmas, and re-fertilized mantle veins, such as wehrlites [Vannucci et al., 2007]. The origin of the Grenada $\mathrm{C}$-series, however, is beyond the scope of this paper, and is not discussed further.

[20] We thus focus on MIs entrapped in $\mathrm{Fo}_{91}$ to $\mathrm{Fo}_{86}$ olivines, which have the most primitive compositions $\left(\mathrm{SiO}_{2}<48 \mathrm{wt} \%\right)$ and low alkali contents $\left(\mathrm{K}_{2} \mathrm{O}<1.0 \mathrm{wt} \%\right.$; Table 2). Specific attention has been paid to the effect of post-trapping crystallization of olivine on the MIs composition. Measured $K_{\mathrm{D}} \quad$ ol/melt values $\left[(\mathrm{FeO} / \mathrm{MgO})_{\mathrm{ol}} /(\mathrm{FeO} / \mathrm{MgO})_{\text {melt }}\right]$ range from 0.12 to 0.29 , whereas the theoretical $K_{\mathrm{D}}$ value, calculated using Toplis' $K_{\mathrm{D}}$ model [Toplis, 2005], averages $0.29 \pm 0.01$ at $1200^{\circ} \mathrm{C}$ and 510 kbar. We verified that the $\mathrm{FeO}_{\mathrm{TO}}$ range measured in MIs is comparable to that of Grenada M-series whole rocks (7.1-10.9 wt\% $\mathrm{FeO}_{\text {TOT; }}$; [Devine, 1995; Thirlwall et al., 1994, 1996; Turner et al., 1996; Van Soest et al., 2002; Woodland et al., 2002]). The extents of post-entrapment crystallization (PEC) of olivine were thus assessed using Petrolog software [Danyushevsky et al., 2000], assuming a $\left[\mathrm{Fe}_{2} \mathrm{O}_{3} /\left(\mathrm{FeO}+\mathrm{Fe}_{2} \mathrm{O}_{3}\right)\right]$ ratio of 0.26 . The latter value is deduced from the available experimental data for $f \mathrm{O}_{2}(\Delta \mathrm{NNO}+1.3)$ of the Lesser Antilles magmas [Devine, 1995; Heath et al., 1998; Pichavant and MacDonald, 2003; Pichavant et al., 2002]. Major and volatile elements contents discussed hereafter are corrected for PEC, a correction which varies from 3 to $18 \%$ and averages at $9 \pm 4 \%$ (Table 2).

[21] Melt inclusions have $\mathrm{MgO}$ contents from 6.8 to $12.7 \mathrm{wt} \%$ (Figure $4 \mathrm{~b}$ ). They delineate a domain that bridges the Grenada picritic and $\mathrm{M}$-series lavas with respect to $\mathrm{MgO}$ [Devine, 1995; Macdonald et al., 2000; Thirlwall et al., 1996], but toward Ca-rich compositions ( $\mathrm{CaO}$ up to $\sim 16.3 \mathrm{wt} \%$ ). $\mathrm{MgO}$ contents as high as $16.2 \mathrm{wt} \%$, as measured in $\mathrm{M}$-series lavas, have not been found in the MIs reported here. This feature suggests that olivine xenocrysts ubiquitous in whole rocks have artificially increased the $\mathrm{MgO}$ contents of the bulk rocks [Devine, 1995; Thirlwall et al., 1996]. 


\subsection{SIMS Data}

[22] Forty basaltic MIs (Figure 4b) entrapped in $\mathrm{Fo}_{87-92}$ were analyzed by ion microprobe for volatile and light elements $\left(\mathrm{H}_{2} \mathrm{O}, \mathrm{Li}, \mathrm{B}, \mathrm{Cl}, \mathrm{S}\right)$ and their isotopes $\delta^{7} \mathrm{Li}, \delta^{11} \mathrm{~B}$, and $\delta \mathrm{D}$ (Table 2). Our data set includes a few open glass embayments possibly affected by superficial degassing processes.

\subsubsection{Volatiles and Light Element Compositions}

[23] Water concentrations of the MIs range from 0.16 to $6.4 \mathrm{wt} \%$, with $80 \%$ of the values between 0.16 and $1.8 \mathrm{wt} \%, 20 \%$ between 2 and $4.5 \mathrm{wt} \%$ and a single value of $6.4 \mathrm{wt} \%$ (Figure 5a and Table 2). When several MIs were measured in a single crystal, their water contents display only moderate differences (e.g., 0.5 and $0.8 \mathrm{wt} \%$, respectively, in G05-28 a, b: and 4.0 and $3.1 \mathrm{wt} \%$, respectively, in $101 \mathrm{a}, \mathrm{b})$. Water and $\mathrm{Cl}$ contents do not correlate, but $\mathrm{H}_{2} \mathrm{O}$ concentrations $<0.5 \mathrm{wt} \%$ were measured in MIs having up to $3500 \mathrm{ppm} \mathrm{S}$ (Table 2), excluding therefore a late degassing as observed for the embayments. Actually, this process is clearly identified in two embayments which, as verified optically, remained in contact with their surrounding, and display lower volatile contents than the fully enclosed MIs. As an example, olivine 104 hosts a melt with $6.4 \mathrm{wt} \% \mathrm{H}_{2} \mathrm{O}(104 \mathrm{a})$, whereas the glass embayment contains no more than $0.9 \mathrm{wt} \%$ $\mathrm{H}_{2} \mathrm{O}(104 \mathrm{~g})$ and is relatively depleted in $\mathrm{S}$ and $\mathrm{Cl}$ (Table 2) compare to the MI. Similarly, in olivine G05-46 the glass embayment (46g1) is depleted in $\mathrm{H}_{2} \mathrm{O}(0.2 \mathrm{wt} \%)$ and $\mathrm{Cl}(320 \mathrm{ppm})$ relative to the MIs $\left(\mathrm{H}_{2} \mathrm{O}=0.5-0.8 \mathrm{wt} \% ; \mathrm{Cl}=2850 \mathrm{ppm}\right)$, and even to an isolated entrapped glass (46g2; Table 2).

[24] Chlorine contents in Grenada MIs, varying from 412 to $3331 \mathrm{ppm}$ (Figure 5b), are by far higher than those of uncontaminated MORB ( $1 \pm$ $0.5 \mathrm{ppm}$ [Saal et al., 2002]), but bracket the $\mathrm{Cl}$ range of subduction-related basalts (500 to $2000 \mathrm{ppm}$ [Wallace, 2005]). Sulphur abundances display a surprisingly large variation, from 96 to $3520 \mathrm{ppm}$ (Figure 5c), and display no evidence of liquid sulphide immiscibility. A subset of MIs has S contents akin to MORB (S from 800 to $1500 \mathrm{ppm}$ [Wallace and Carmichael, 1992]). The lowest S contents $(96-<600 \mathrm{ppm})$ are associated with variable $\mathrm{Cl}$ (0.1-0.3 wt\%) and $\mathrm{H}_{2} \mathrm{O}(0.9-3.6 \mathrm{wt} \%)$ contents.

[25] Boron and Li concentrations in MIs also vary widely, from 1.7 to $47 \mathrm{ppm}$ for B (Figure 5d) and from 1.8 to $19 \mathrm{ppm}$ for Li (Figure 5e). Most $\mathrm{Li}$ concentrations are similar to MORB values (from
2.9 to $7.8 \mathrm{ppm}$ [Tomascak et al., 2008]), whereas MIs are enriched in B relative to MORB (0.34 to 0.74 ppm B [Chaussidon and Jambon, 1994]), as observed for $\mathrm{Cl}$ contents.

\subsubsection{Isotopic Compositions}

[26] Values of $\delta^{11} \mathrm{~B}(-19.6$ to $+8.9 \%$, Figure $5 \mathrm{f})$ bracket those of MORB (-6.5 to $-1.5 \%$ [Chaussidon and Jambon, 1994]), but most MIs have higher $\delta^{11} \mathrm{~B}$. Similarly, $\delta^{7} \mathrm{Li}$ varies widely, from $+8.2 \%$ to $-6.2 \%$, with one value of $-23.6 \%$ o (Figure $5 \mathrm{~g}$ ). Half of MIs have $\delta^{7} \mathrm{Li}$ values lower than unaltered MORB (+3.4 to $+4.7 \%$ [ [Tomascak et al., 2008]).

[27] $\delta \mathrm{D}$ measurements were performed on 16 MIs covering the range of measured $\mathrm{H}_{2} \mathrm{O}$ concentrations $(0.21$ to $6.4 \mathrm{wt} \%)$. The measured $\delta \mathrm{D}$ range from -202 to $-8.5 \%$ (Figure $5 \mathrm{~h}$ ), but most cluster between -100 and $-175 \%(n=10)$ regardless of the $\mathrm{H}_{2} \mathrm{O}$ content (Figure 6). These values are significantly lighter than those of MORB ( -60 to -80\% [Craig and Lupton, 1976; Kyser and O'Neil, 1984; Pineau and Javoy, 1994; Sheppard and Dawson, 1973]).

\section{Discussion}

[28] Basaltic to picritic MIs record significant variability in volatile, light element and isotopic compositions, with no distinction between the different layers sampled in Queen's Park cone. We underline that the olivine chemical zoning has been preserved. We did not find significant melt-olivine $\mathrm{Fe}$ re-equilibration via Fe diffusion, despite the fact that $\mathrm{Fe}$ has a high diffusion coefficient $(5.38 \pm$ $0.89 \mu \mathrm{m}^{2} / \mathrm{s}$ [Chakraborty, 1997]). These features are broadly consistent with rapid magma transfer toward the surface, as previously suggested [Devine, 1995].

[29] The main characteristics of Grenada MIs are: i) the prevalence of low $\mathrm{H}_{2} \mathrm{O}$ contents (Figures 5a and 6), ii) an overall low $\delta \mathrm{D}$ composition $(<-100 \%$ ) not correlated with $\mathrm{H}_{2} \mathrm{O}$ (Figure 6), iii) their enrichment in $\mathrm{B}$ and $\mathrm{Cl}$ (Figures $5 \mathrm{~b}$ and $5 \mathrm{c}$ ), and finally noticeable variations of $\delta^{11} \mathrm{~B}$ and $\delta^{7} \mathrm{Li}$.

\subsection{Water Contents in Grenada Melt Inclusions: Secondary Processes or Source Signature?}

[30] A large proportion of MIs (40\%) displays low $\mathrm{H}_{2} \mathrm{O}$ concentrations $(0.16-0.5 \mathrm{wt} \%)$, in the range of 

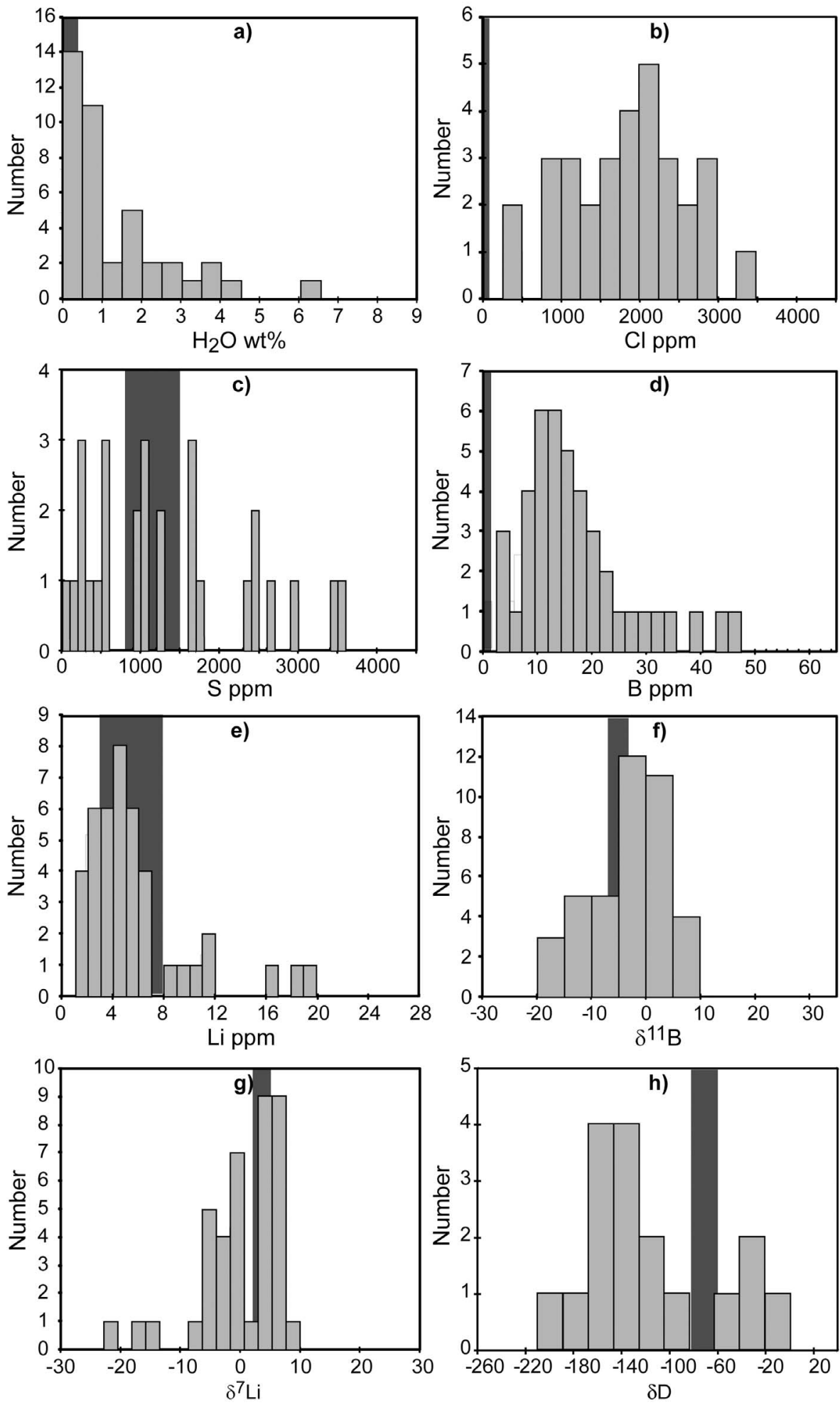

Figure 5. Compositional distributions for (a) water, (b) chlorine, (c) sulfur, (d) boron, (e) lithium, (f) $\delta^{11} \mathrm{~B},(\mathrm{~g}) \delta^{7} \mathrm{Li}$ and (h) $\delta \mathrm{D}$ in Grenada MIs. Typical MORB values are reported for each element (black bars): Figure 5a, Chaussidon et al. [1991]; Figure 5b, Saal et al. [2002]; Figure 5c, Wallace and Carmichael [1992]; Figures 5d-5f, Chaussidon and Jambon [1994]; Figures 5e-5g, Tomascak et al. [2008]; Figure 5h, Craig and Lupton [1976], Kyser and O'Neil [1984], Pineau and Javoy [1994], and Sheppard and Dawson [1973]. 


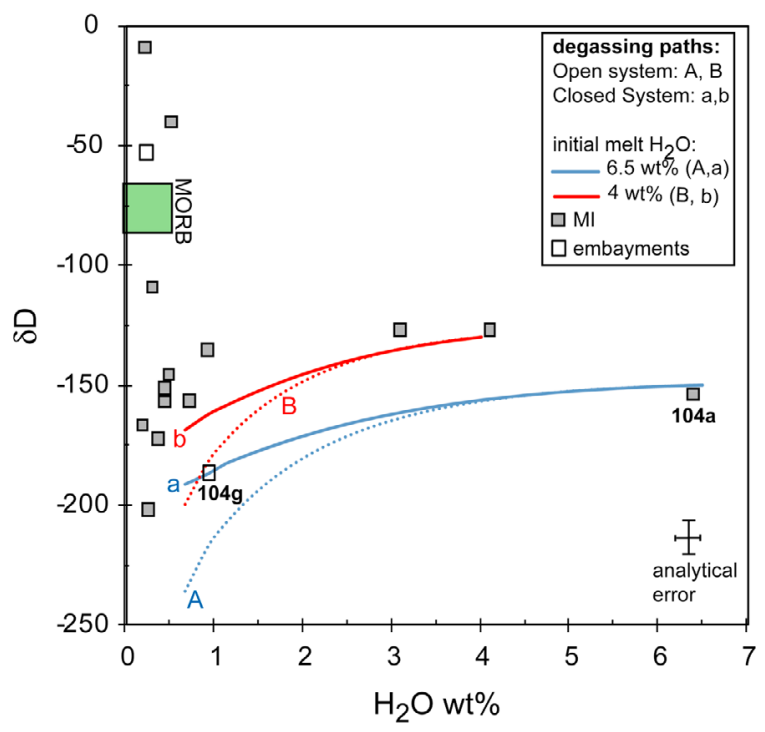

Figure 6. Plot of $\delta$ D versus $\mathrm{H}_{2} \mathrm{O}$ in Grenada MIs. MORB domain is plotted for comparison [Craig and Lupton, 1976; Kyser and O'Neil, 1984; Pineau and Javoy, 1994; Sheppard and Dawson, 1973]. Degassing paths have been calculated for open- (curves A and B) and closed- (curves a and b) system conditions. Partition coefficients $\alpha_{\mathrm{H} 2 \mathrm{Ov}-\mathrm{H} 2 \mathrm{Om}}$ and $\alpha_{\mathrm{H} 2 \mathrm{Ov}-\mathrm{OHm}}$ used for calculations are from De Hoog et al. [2009] and Newman et al. [1988]. Most of $\delta \mathrm{D}$ values are significantly lower than MORB values ( -60 to $-80 \%$ ), and not correlated with the amount of dissolved $\mathrm{H}_{2} \mathrm{O}$. Open-system degassing cannot reproduce Grenada MIs compositions, whereas closed-system degassing may explain the composition of the glass embayment $104 \mathrm{~g}$, compare to the fully enclosed MI 104a.

unaltered MORB (0.06-0.5 wt\% [Chaussidon et al., 1991; Michael, 1995]), whereas others have up to $4 \mathrm{wt} \% \mathrm{H}_{2} \mathrm{O}$ (exceptionally $6 \mathrm{wt} \%$ ). The significance of $\mathrm{H}_{2} \mathrm{O}$ in natural, unheated MIs is strongly debated [Danyushevsky et al., 2002b; Portnyagin et al., 2008]. Low $\mathrm{H}_{2} \mathrm{O}$ contents in arc-related magmas were previously reported for high-alumina basalts from the Cascades arc Black Crater [Sisson and Layne, 1993] and magnesian basalts from Galunggung in Indonesia [Sisson and Bronto, 1998]. They have been interpreted to be produced by mantle upwelling and pressure-release melting. In these samples, low $\mathrm{H}_{2} \mathrm{O}$ contents are coupled with low $\mathrm{K}_{2} \mathrm{O}$ and trace element patterns of MORB-type magmas. Adiabatic decompression melting of a nearly anhydrous, metasomatized mantle wedge was also invoked to account for the trace element pattern of $\mathrm{MgO}$-rich, $\mathrm{H}_{2} \mathrm{O}$-poor MIs hosted in olivine $\mathrm{Fo}_{89-92}$ from the Marianna arc [Kohut et al., 2006]. Grenada MIs display no co-variation between $\mathrm{H}_{2} \mathrm{O}$ and $\mathrm{K}_{2} \mathrm{O}$, as $\mathrm{H}_{2} \mathrm{O}$ widely varies (from 6.5 to $0.5 \mathrm{wt} \%$ ) within a very restricted range of $\mathrm{K}_{2} \mathrm{O}$ concentrations (0.53$0.58 \mathrm{wt} \%$ ). They are significantly enriched in $\mathrm{Cl}$ and B compared to MORB (Figure 4), which is apparently inconsistent with low water contents, because $\mathrm{Cl}$ and $\mathrm{B}$ are thought to be mobilized by aqueous fluids. As an illustration, coeval increase of $\mathrm{B}, \mathrm{Li}$ and $\mathrm{H}_{2} \mathrm{O}$ is observed in serpentinite rocks [Vils et al., 2008]. Straub and Layne [2003b] found basaltic MIs (48.6-53.1 wt $\left.\% \mathrm{SiO}_{2}, 5-6.6 \mathrm{wt} \% \mathrm{MgO}\right)$, in fallout tephra from the Izu arc, strongly enriched in $\mathrm{B}(9-14 \mathrm{ppm}), \mathrm{Cl}(540-1313 \mathrm{ppm})$ and $\mathrm{H}_{2} \mathrm{O}(2.6-$ $5.5 \mathrm{wt} \%)$ compared to MORB. These enrichments are interpreted by the authors as reflecting the influence of slab dehydration fluids, rich in $\mathrm{H}_{2} \mathrm{O}$, B and Cl. Similarly, Le Voyer et al. [2010] report positive correlations between $\mathrm{H}_{2} \mathrm{O}, \mathrm{Cl}$ and $\mathrm{B}$ in Mt. Shasta basaltic melts. Hence, the different processes which would explain the generation of $\mathrm{H}_{2} \mathrm{O}$-poor melts enriched in $\mathrm{Cl}$ and $\mathrm{B}$ are examined.

\subsubsection{Post-entrapment Evolution of Water}

[31] Post-entrapment diffusion may strongly affect the $\mathrm{H}_{2} \mathrm{O}$ concentrations in olivine-hosted MIs [e.g., Danyushevsky et al., 2002b; Portnyagin et al., 2008]. This process, however, is thought to be limited during rapid magma decompression and cooling [e.g., Johnson et al., 2010; Shaw et al., 2008], as shown by high $\mathrm{H}_{2} \mathrm{O}$ concentrations preserved in olivine hosted basaltic MIs (up to $5 \mathrm{wt} \%$ [Cervantes and Wallace, 2003]). Proton $\left(\mathrm{H}_{2}\right)$ diffusion was invoked to explain $\mathrm{H}_{2} \mathrm{O}$ loss from $\mathrm{MI}$ hosted in olivine [Danyushevsky et al., 2002a; Hauri, 2002], owing to the high diffusivity of these species in olivine [Mackwell and Kohlstedt, 1990]. Moreover, Gaetani et al. [2009] proposed that water loss or gain involves exchange between $\mathrm{O}^{2-}$ and $2 \mathrm{H}^{+}$. Hence, the $\mathrm{Fe}$ redox reaction would not limit the water loss rate, as previously thought [Danyushevsky et al., 2002a]. Diffusion of $\mathrm{H}^{+}$or $\mathrm{H}_{2}$ drives the melt $\delta \mathrm{D}$ compositions toward heavy values, up to $+46 \%$ [Xia et al., 2002] or $+140 \%$ [Hauri, 2002]. Any water loss via proton diffusion is thus possibly tracked by significant change in hydrogen isotopes [Hauri, 2002]. In Grenada MIs, the $\delta \mathrm{D}$ values cluster between -109 and $-202 \%$ (except $3 \quad \delta \mathrm{D}$ values between -51 and $-8 \%$ ) regardless of their $\mathrm{H}_{2} \mathrm{O}$ content (Figure 5). Negative $\delta \mathrm{D}$ values suggest that water-loss out of MI via proton diffusion through the host olivine lattice is not the dominant process that may account for the presence of both high and low $\mathrm{H}_{2} \mathrm{O}$ contents in Grenada MIs. Conversely, assuming $\mathrm{H}_{2} \mathrm{O}$ loss via proton diffusion, the $\delta \mathrm{D}$ values could have been initially even more negative. Moreover, the $\mathrm{H}_{2} \mathrm{O}$ 
loss of $\geq 3.5 \mathrm{wt} \%$ would cause post-entrapment olivine crystallization [e.g., Danyushevsky et al., 2002a], whereas there is no systematic relation between PEC and water content in Grenada MIs. No relation is observed between vapor bubble size and water content.

[32] We cannot exclude that MIs with low $\mathrm{H}_{2} \mathrm{O}$ concentrations (in the range of MORB values) may have been subject to post-entrapment $\mathrm{H}_{2} \mathrm{O}$ loss but we suggest that most of them represent magma batches initially depleted in $\mathrm{H}_{2} \mathrm{O}$.

\subsubsection{Evolution Paths of $\mathrm{H}_{2} \mathrm{O}$ and $\delta \mathrm{D}$ Under Open- and Closed-System Conditions}

[33] We examine here the effect of magma degassing on $\mathrm{H}_{2} \mathrm{O}$ and $\delta \mathrm{D}$, under open- and closedsystem conditions following the equations 1 and 2 , respectively:

$$
\begin{gathered}
\delta \mathrm{D}_{\mathrm{m}}=\delta \mathrm{D}_{0}-\left[\left(1-\mathrm{F}^{\alpha \mathrm{v}-\mathrm{m}-1}\right) \times\left(\delta \mathrm{D}_{0}+1000\right)\right] \\
\delta \mathrm{D}_{\mathrm{m}}=\delta \mathrm{D}_{0}-\left[(1-\mathrm{F}) \times \alpha_{\mathrm{v}-\mathrm{m}}\right]
\end{gathered}
$$

The bulk isotopic fractionation factor is defined as:

$$
\begin{aligned}
\alpha_{\mathrm{v}-\mathrm{m}}= & \delta \mathrm{D}_{\mathrm{v}}-\delta \mathrm{D}_{\mathrm{m}}=\left(\mathrm{X}_{\mathrm{H} 2 \mathrm{O}}\right)_{\mathrm{m}} 10^{3} \ln \alpha_{\mathrm{H} 2 \mathrm{Ov}-\mathrm{H} 2 \mathrm{Om}} \\
& +\left(\mathrm{X}_{\mathrm{OH}}\right)_{\mathrm{m}} 10^{3} \ln \alpha_{\mathrm{H} 2 \mathrm{Ov}-\mathrm{OHm}}
\end{aligned}
$$

For these equations: $m$ is melt, $v$ vapor, $\delta \mathrm{D}_{0}$ the initial value and $F$ the mass fraction of water exsolved from the melt. The fractionation factors $\alpha_{\mathrm{H} 2 \mathrm{Ov}-\mathrm{H} 2 \mathrm{Om}}$ and $\alpha_{\mathrm{H} 2 \mathrm{Ov}-\mathrm{OHm}}$ are from Newman et al. [1988] and De Hoog et al. [2009]. The relative fractions of $\mathrm{OH}$ and molecular $\mathrm{H}_{2} \mathrm{O}$ during degassing have been calculated using VolatileCalc [Newman and Lowenstern, 2002], assuming $\mathrm{a} \mathrm{SiO}_{2}$ melt content of $45 \mathrm{wt} \%$, representative of Grenada MIs and a temperature of $1200^{\circ} \mathrm{C}$. Figure 6 illustrates the evolution paths of $\mathrm{H}_{2} \mathrm{O}$ and $\delta \mathrm{D}$ under open-system (curves A and B), and closed-system (curves $\mathrm{a}, \mathrm{b}$ ) conditions, starting from melts having distinct $\mathrm{H}_{2} \mathrm{O}$ contents $(6.5$ and 4 wt $\%)$ and $\delta \mathrm{D}$ values $(-150$ and $-127 \%)$. The curves $(\mathrm{A}, \mathrm{B})$ computed for open-system conditions do not reproduced the $\delta \mathrm{D}$ values from -109 to $-202 \%$ measured in water-poor MIs. Conversely, the lowest $\delta \mathrm{D}$ values of -170 and $-200 \%$ would require an initial melt isotopic composition lower than or close to MORB values ( $-80 \%$ [Craig and Lupton, 1976; Kyser and O'Neil, 1984; Pineau and Javoy, 1994; Sheppard and Dawson, 1973]). This feature is inconsistent with the overall enrichment in $\mathrm{B}$ and $\mathrm{Cl}$ observed in MIs. Closed-system degassing (curve a) of a melt with $6.5 \mathrm{wt} \%$ of $\mathrm{H}_{2} \mathrm{O}$ (MI 104a) possibly explains the low $\mathrm{H}_{2} \mathrm{O}$ content $(0.93 \mathrm{wt} \%)$ and light $\delta \mathrm{D}$ value $(-186 \%)$ of the glass embayment $(104 \mathrm{~g})$ entrapped in the same olivine. The MIs cluster with low water content $(<0.5 \mathrm{wt} \%)$ and $\delta \mathrm{D}$ around $-170 \%$ are possibly reproduced by magma degassing under closedsystem conditions (curve b). However, high $\mathrm{S}$ contents in these MIs are inconsistent with late stage degassing at low pressure, since sulphur vapor-melt partitioning increases with decreasing pressure [Holzheid and Grove, 2002; Johnson et al., 2010]. Alternatively, early water removal from basaltic melts via $\mathrm{CO}_{2}$-magma fluxing [e.g., Johnson et al., 2008; Spilliaert et al., 2006] is a suitable process to account for low water contents recorded by the majority of Grenada MIs. However, an extensive $\mathrm{H}_{2} \mathrm{O}$ exsolution $(>90 \%$ ) would cause a drastic increase of the melt liquidus temperature, changes in the mineral assemblage and finally extensive melt crystallization [Sisson and Grove, 1993], whereas there is no correlation between $\mathrm{H}_{2} \mathrm{O}$ content and MIs composition. Following this line of reasoning, Grenada MIs would record magma batches variably enriched in $\mathrm{H}_{2} \mathrm{O}$, even though the very low $\mathrm{H}_{2} \mathrm{O}$ values are not considered to be representative of the initial melts.

[34] The most striking feature is the negative $\delta \mathrm{D}$ values measured in Grenada MIs, even in the richest in $\mathrm{H}_{2} \mathrm{O}$. Such hydrogen isotopic signature could be inherited from slab fluids. Indeed, D/H fractionation factors between fluid and hydrous minerals are nearly all in agreement with partitioning of $\mathrm{D}$ into the fluid relative to $\mathrm{H}(\alpha>1$ [Suzuoki and Epstein, 1976]), leaving low $\delta \mathrm{D}$ signature in the subducting slab. Shaw et al. [2008] have suggested that the early fluids released by the slab would have $\delta \mathrm{D}$ of $\sim-34 \%$. With increasing dehydration depth, the $\delta \mathrm{D}$ values of the subducting slab would decrease from $-50 \%$ o (nearly all the initial water content remaining in the slab) to $-234 \%$ (advanced stage of dehydration: $8 \%$ of initial water content remaining into the slab), leading to a $\delta \mathrm{D}$ decrease in the dehydration slab fluids from $-34 \%$ to $-200 \%$.

\subsection{Slab-Fluid Influence on the Mantle Source Beneath Grenada}

\subsubsection{Modeling $B$ and $\delta^{11} B$ Evolution in Melt: Basic Considerations}

[35] The B concentrations of Grenada MIs are by far higher than those of MORB and vary widely 


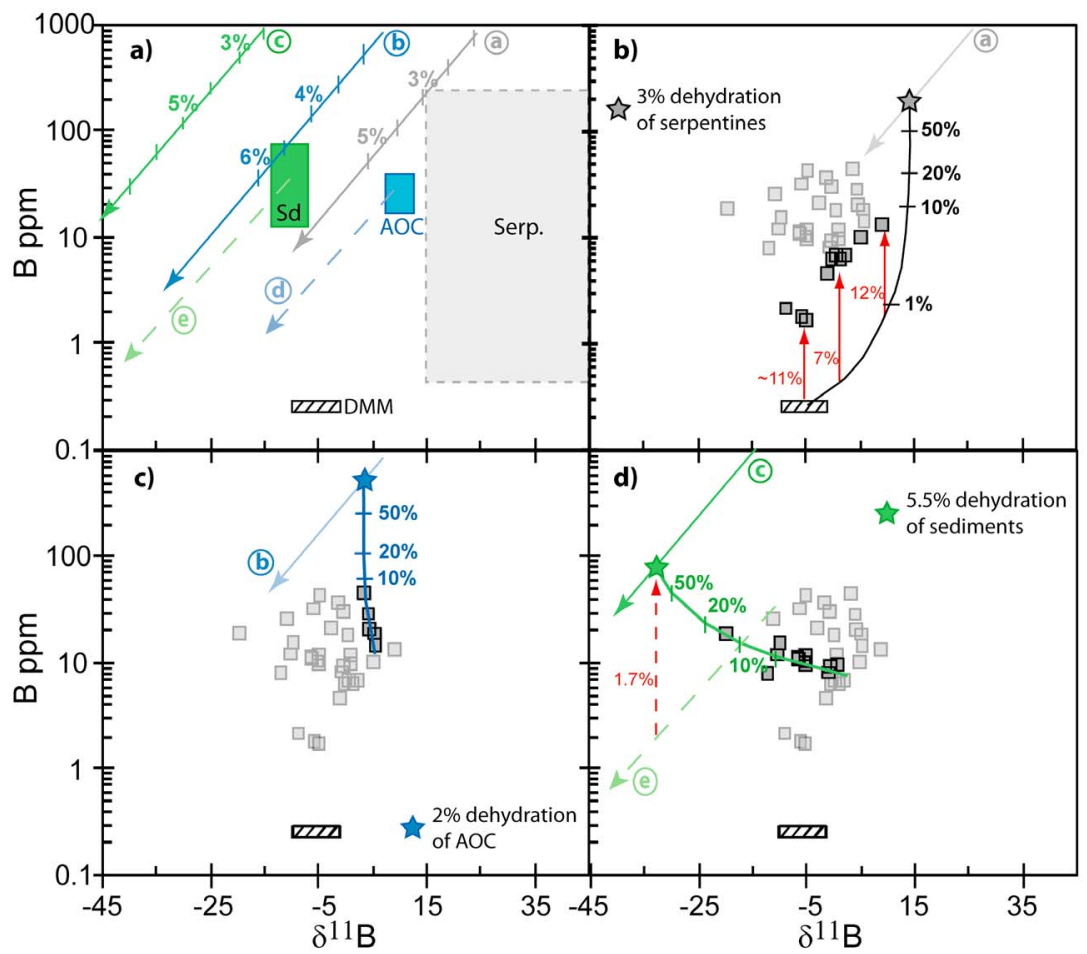

Figure 7. Modeling the $\mathrm{B}$ and $\delta^{11} \mathrm{~B}$ evolution. The so-called boron model has been modified from Rose et al. [2001] and applied to Grenada samples. (a) Diagram showing the end-members for B and $\delta^{11} \mathrm{~B}$ modeling: MORB-type mantle source (DMM [Chaussidon and Marty, 1995]) serpentines (Serp., gray field [Benton et al., 2001; Savov et al., 2005; Vils et al., 2008, 2009]), and altered oceanic crust (AOC, bleu field [Chaussidon and Libourel, 1993; Chaussidon and Jambon, 1994; Spivack and Edmond, 1987]). For sediments (Sd; green field), we used the B contents analyzed in this work in sediments from Lesser Antilles DSDP Site 144 sediments (Table A4), and $\delta^{11} \mathrm{~B} \sim-10 \%$ [Smith et al., 1997]. The elemental and isotopic B compositions of dehydrated residues and of the extracted dehydration fluids are calculated using a Rayleigh distillation model assuming $\mathrm{D}_{\mathrm{B}}^{\text {fluid/solid }}=50$ [Rose et al., 2001] and isotopic fractionation between fluid and solid $\Delta_{\mathrm{f}-\mathrm{s}}+5 \%$. Theoretical trajectories for the fluids produced by variable extents of B loss during dehydration (expressed in \%) are represented by the solid lines (labeled a for dehydration fluids from serpentines, $\mathrm{b}$ for fluids from $\mathrm{AOC}$ and $\mathrm{c}$ for fluids from sediments). Theoretical evolution paths of variably dehydrated solids are represented by light dashed lines (labeled d for dehydrated AOC and e for dehydrated sediments). Curve a is bracketed by dashed lines taking into account different serpentine compositions. The parameters used here are summarized in Table A3. Modeling of (b) the mixing between serpentine-derived fluids and the mantle source and of the contributions of fluids derived from (c) AOC and (d) sediments. In each plot, the percentages indicated on the mixing curves refer to the proportion of B added to the source or melt by the specific fluids, and the MIs compositions fitted by the calculations are emphasized (dark squares). In Figure $7 \mathrm{~b}$, emphasized data points are fitted by variable extents of melting (7-12\%) of a B-enriched mantle source. In Figure $7 \mathrm{~d}$, the sediment-derived component could be produced by $1.7 \%$ of melting of dehydrated sediments.

(from 1.7 to $45 \mathrm{ppm}$ ) as do their isotopic compositions $\left(\delta^{11} \mathrm{~B}=-19.6\right.$ to $\left.+8.9 \%\right)$. Similar variations in both $\mathrm{B}$ content ( 8 to $53 \mathrm{ppm}$ ) and isotopic composition $\left(\delta^{11} \mathrm{~B}=-25.6\right.$ to $+11 \%$ ) have been measured in basaltic MIs from the nearby St. Vincent island [Bouvier et al., 2008]. In the Ecuadorian arc, a large range of $\mathrm{B}$ and $\delta^{1 \mathrm{1}} \mathrm{B}$ values is also reported in samples from the front arc $\left(\delta^{11} \mathrm{~B}\right.$ from -9.5 to $+3.5 \%)$ and back arc $\left(\delta^{11} \mathrm{~B}\right.$ from -17.9 to $\left.+1.9 \%\right)$ volcanoes [Le Voyer et al., 2008]. In each case, the $\mathrm{B}$ and $\delta^{11} \mathrm{~B}$ variations were related to the influence of slab-derived fluids.
[36] To constrain both the nature and the contributions of slab-derived fluids to the mantle wedge beneath Grenada, we used the $\mathrm{B}$ versus $\delta^{11} \mathrm{~B}$ model (Figure 7a; so-called Boron model), following Rose et al. [2001]. These authors used Rayleigh distillation to calculate the theoretical B and $\delta^{11} \mathrm{~B}$ compositions of the fluids released during the dehydration of altered oceanic crust (AOC) and subducted sediments, and those of the dehydrated residual components.

[37] In the present work, we have extended the model proposed by Rose et al. [2001]. First, we 
have considered the possible influence of the early dehydration of serpentines on the B budget. Second, it is suggested that fluids issued from AOC and sediments might have distinct $\mathrm{B}$ and $\delta^{11} \mathrm{~B}$ compositions [Rose et al. 2001; Le Voyer et al. 2008], as also discussed for the nearby St. Vincent Island in the Lesser Antilles arc [Bouvier et al., 2008]. The large number of measurements carried out on Grenada MIs allows us to discuss the respective influence of fluids generated by variable extents of dehydration of AOC and subducted sediments. Parameters and the composition of the main reservoirs used for calculations are listed in Table A3. The isotopic fractionation factor between fluid and solid $\left(\Delta \mathrm{B}_{\mathrm{f}-\mathrm{s}}\right)$ is assumed to be $+5 \%$ and the partition coefficient between solid and fluid ( $\mathrm{D}_{\mathrm{B}}^{\text {solid/fluid }}$ ) is taken as 0.015 [Rose et al., 2001], neglecting the possible effects of temperature variations. This model is limited by the lack of constraints on such parameters as $\mathrm{D}_{\mathrm{B}}^{\text {solid/fluid, which }}$ may vary with the degree of metamorphism during subduction [Marschall et al., 2007b]. Figure 7a illustrates the theoretical $\mathrm{B}$ and $\delta^{11} \mathrm{~B}$ compositions of slab-fluids produced during dehydration of serpentine (curve a), AOC (curve b) and sediment (curve c), and of their residual components (curves $\mathrm{d}$ and e for AOC and sediments, respectively). The fluids released by the early dehydration of either the altered oceanic crust, sediments or serpentines are strongly enriched in $\mathrm{B}$ and have higher $\delta^{11} \mathrm{~B}$ than their solid residues. With the increase of the degree of dehydration, compositions in $\mathrm{B}$ and $\delta^{11} \mathrm{~B}$ of released fluids and dehydrated residues decrease.

[38] For serpentines, we used the B contents from 0.3 to $120 \mathrm{ppm}$ and isotopic compositions from 10 to 40.5\% [Benton et al., 2001; Savov et al., 2005; Vils et al., 2009]. These values are for serpentinized oceanic peridotites, formed by seafloor alteration [Vils et al., 2009] and serpentinized peridotites formed above the slab in the mantle wedge [Benton et al., 2001; Savov et al., 2005]. We choose to take into account these two serpentine types because serpentinized wedge compositions have been published only for the Marianna arc. However, sediments subducted beneath the Marianna arc are different than those present in the Lesser Antilles arc. Indeed, the buried sediments in the Marianas are pelagic clays [Plank et al., 2000] rich in B (54132 ppm [Ishikawa and Nakamura, 1993]), whereas they vary from silicic pelagic sediments to carbonates and black shales [Carpentier et al., 2008], with slightly lower B contents (11-120 ppm B; Table A4) in Lesser Antilles arc. So the use of oceanic peridotites, altered by a fluid close to seawater, and Mariana serpentines, altered by early peliagic sediment dehydration, covers a large range of compositions that may encompass the Lesser Antilles serpentinized wedge.

[39] For Lesser Antilles sediments, we considered the B contents of black shales, carbonates, zirconbearing sand of DSDP site 144 (south part of the Lesser Antilles arc) and silicic pelagic sediments from DSDP site 543 (north part of the arc), which were specifically analyzed in the present study (Table A4). Lesser Antilles sediments have $\delta^{11} \mathrm{~B}$ of $-10 \%$, representative of structural boron present in sediments (see Smith et al. [1997] for a review). Boron contents of DMM and AOC are from Chaussidon and Marty [1995] and Chaussidon and Libourel [1993], Chaussidon and Jambon [1994], and Spivack and Edmond [1987], respectively.

\subsubsection{Serpentine Dehydration-Derived Fluids}

[40] The overall B enrichment in MIs with respect to MORB requires the melting of a DMM-mantle source previously enriched in $\mathrm{B}$ and $\delta^{11} \mathrm{~B}$. Fluids especially enriched in ${ }^{11} \mathrm{~B}$ are possibly generated during serpentines dehydration [e.g., Straub and Layne, 2003a]. We thus considered this hypothesis assuming that serpentine rocks are formed by mantle wedge alteration via fluids released during the very early stage of slab subduction, while their dehydration occurs when they are dragged down by the slab. In Figure $7 \mathrm{~b}$, the fluid-mantle mixing curve (black curve) is calculated taking into account a fluid having $208 \mathrm{ppm} \mathrm{B}$ and $\delta^{11} \mathrm{~B}$ of $14 \%$ o (gray star), corresponding to $\sim 3 \%$ serpentine dehydration, and a DMM source with an initial average composition of $0.25 \mathrm{ppm} \mathrm{B}$ and $\delta^{11} \mathrm{~B}$ of $-5 \%$. A part of MIs data (Figure $7 \mathrm{~b}$ ) can be reproduced by $7-12 \%$ of melting of this DMMtype mantle variably enriched in $\mathrm{B}$ and $\delta^{11} \mathrm{~B}$ by the addition of less than $1 \%$ of $\mathrm{B}$ from the fluid generated during serpentine dehydration. As serpentine dehydration fluids are also Cl-rich [e.g., Marschall et al., 2007a], that is consistent with the overall MIs enrichment in $\mathrm{Cl}$.

[41] Serpentinized oceanic peridotites are Li poor (0.1-4 ppm [e.g., Decitre et al., 2002; Scambelluri et al., 2004; Vils et al., 2009]), whereas serpentinized wedge peridotites (Mariana arc) have been found to be richer in Li ( $\sim 6 \mathrm{ppm}$ [Benton et al., 2004; Savov et al., 2005]). However, as described above, sediments subducted at the Marianas and beneath Grenada differ by their composition. For the Marianas, the pelagic clays are rich in both $\mathrm{Li}$ (>70 ppm Li [Chan and Kastner, 2000]). In Lesser 


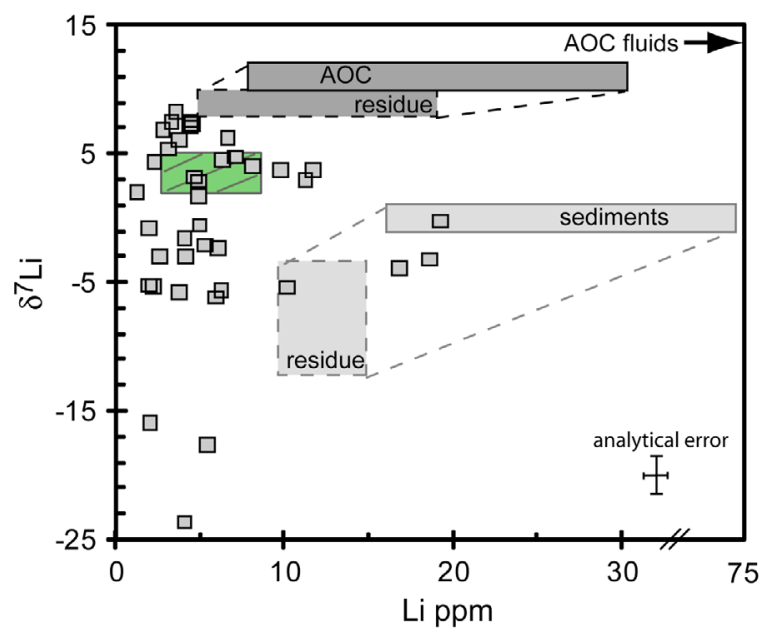

Figure 8. Variations of $\delta^{7} \mathrm{Li}$ compared to Li in Grenada melt inclusions. For comparison data are plotted for MORB [Tomascak et al., 2008], sediments (Table A3 of this study) [Carpentier et al., 2008; Bouman et al., 2004] and the calculated extreme composition of the residual metasediments after dehydration (dashed light gray field [Teng et al., 2007]). The compositions of AOC, dehydrated AOC residue and dehydration fluids derived from AOC (marked with an arrow, their $\mathrm{Li}$ contents being much higher) are from Marschall et al. [2007a]. MI, recording the B signature of AOC dehydration fluids, display an increase of $\mathrm{Li}$ content (up to $17 \mathrm{ppm}$ ) and a slight of $\delta^{7} \mathrm{Li}$ decrease (down to $-5 \%$ ). MI with sediment B-signatures show the lightest $\delta^{7} \mathrm{Li}$ and relatively low $\mathrm{Li}$ contents. The light $\delta^{7} \mathrm{Li}$ could be explained by kinetic fractionation (see text).

Antilles arc, the sediments accumulated in the accretionary prism are dominated by carbonates and black shales [Carpentier et al., 2008], with moderate concentrations in Li (on average 13 ppm; Table A4). Compare to the boron composition of sediments, the difference in $\mathrm{Li}$ contents of the sediments from the Marianas and the Lesser Antilles is larger. Moreover, the relatively high Li partition coefficient between solid and fluids $\left(D_{\mathrm{Li}}^{\text {solid/fluid }} \geq\right.$ 0.3 [Scambelluri et al., 2004]), compared to 0.015 for boron, would lead to relatively low $\mathrm{Li}$ contents in fluids serpentinizing the mantle wedge beneath Grenada. Hence, in the Lesser Antilles arc, serpentinized mantle wedge may have lower Li content than Marianas serpentines, and thus, mantle interactions with fluids from serpentine dehydration would not strongly affect $\mathrm{Li}$ composition of the melts.

\subsubsection{Slab Signatures in Magmas}

[42] The strongest B enrichment (up to $46.7 \mathrm{ppm}$ ), $\delta^{11} \mathrm{~B}$ depletion (down to $-19.6 \%$ ) and Li enrich- ment (up to $19.2 \mathrm{ppm}$ ), cannot be reproduced when considering only serpentine dehydration and require additional contributions. The $\mathrm{B}$ and $\delta^{11} \mathrm{~B}$ compositions of Grenada MIs fall between two main domains: one gathers MIs showing B enrichment (from 15 to $47 \mathrm{ppm}$ ) and positive $\delta^{11} \mathrm{~B}$ values (from 3.4 to $5.5 \%$ ), as shown in Figure $7 \mathrm{c}$ by $\mathrm{MI}$ represented by dark symbols, and the other one includes MI with highly variable and negative $\delta^{11} \mathrm{~B}$ values $(-19.6$ to $-0.7 \%$ ) associated with somewhat low B contents (8.5-19 ppm), as represented in Figure $7 \mathrm{~d}$. The $\mathrm{B}$ and $\delta^{11} \mathrm{~B}$ compositions of the former group are reproduced by the mixing between the melts generated by $7-12 \%$ melting of the B-enriched DMM source and fluid derived from the dehydration of AOC (Figure 7c). The best fit is obtained when considering mixing with a fluid generated by $2 \%$ AOC dehydration $(\mathrm{B}=$ $506 \mathrm{ppm}, \delta^{11} \mathrm{~B}=4 \%$; Figure $7 \mathrm{c}$ and Table $\mathrm{A} 3$ ). Calculations suggest less than $10 \%$ of $B$ added by the AOC fluid. In the other case, MIs with highly variable and negative $\delta^{11} \mathrm{~B}$ values but rather low $\mathrm{B}$ contents would require the contribution of up to $5 \%$ (one MI suggesting $\sim 15 \%$ ) of the B brought by dehydration fluids derived from sediments $(5.5 \%$ sediments dehydration, Figure 7d). Alternatively, such a fluid, having $81 \mathrm{ppm} \mathrm{B}$ and $\delta^{11} \mathrm{~B}=-32.5 \%$, could also be produced by $1.7 \%$ melting of dehydrated sediments. It is thought that sediment melting produces Si-rich melts, depending on the pressure (lower $\mathrm{SiO}_{2}$ at higher pressure [Johnson and Plank, 1999]). According to the latter authors, $30 \%$ melting can generate melts with 53.2 to $76.4 \mathrm{wt} \% \mathrm{SiO}_{2}$. In Grenada samples, low extents of melting of sediments would thus not change the silica-undersaturated nature of MIs. Moreover, sediment melts possibly lose $\mathrm{SiO}_{2}$ while they are reacting with the cooler, lower part of the mantle wedge, via the reaction olivine $+\mathrm{SiO}_{2}=$ orthopyroxene [Carroll and Wyllie, 1989; Zhang and Frantz, 2000].

[43] Grenada MIs populations, with distinct B and $\delta^{11} \mathrm{~B}$ signatures, were also tentatively identified by their $\mathrm{Li}$ content and $\delta^{7} \mathrm{Li}$ signature (Figure 8). It has recently been suggested that the ${ }^{7} \mathrm{Li} /{ }^{6} \mathrm{Li}$ ratio is moderately fractionated during metamorphic devolatilization [Marschall et al., 2007a; Teng et al., 2007], leading to only a small decrease of the $\delta^{7} \mathrm{Li}$ in the dehydrated residue. Due to a higher mobility of ${ }^{7} \mathrm{Li}$ [Tomascak et al., 2000], dehydration fluids have higher $\delta^{7} \mathrm{Li}$ than the lithology from which they derived. More specifically, Marschall et al. [2007a] have modeled the composition of the fluids extracted from average AOC $(\mathrm{Li}=$ 
Table A1. Compositions of Etna Water-Bearing Glass Standards

\begin{tabular}{|c|c|c|c|c|c|c|c|c|c|c|c|c|}
\hline Standard $^{\mathrm{a}}$ & EtIII-0,5a & SD & EtIII- $0,5 b$ & SD & EtIII-1a & $\mathrm{SD}$ & EtIII-1b & SD & EtIII-2a & $\mathrm{SD}$ & EtIII-2b & $\mathrm{SD}$ \\
\hline $\mathrm{SiO}_{2}{ }^{\mathrm{b}}$ & 47.72 & 0.29 & 48.29 & 0.19 & 47.42 & 0.13 & 47.45 & 0.52 & 47.17 & 0.24 & 47.48 & 0.26 \\
\hline $\mathrm{TiO}_{2}{ }^{\mathrm{b}}$ & 1.73 & 0.06 & 1.70 & 0.11 & 1.67 & 0.09 & 1.70 & 0.11 & 1.66 & 0.12 & 1.61 & 0.09 \\
\hline $\mathrm{Al}_{2} \mathrm{O}_{3}{ }^{\mathrm{b}}$ & 16.09 & 0.16 & 16.32 & 0.10 & 15.76 & 0.12 & 15.98 & 0.20 & 15.90 & 0.12 & 16.06 & 0.09 \\
\hline $\mathrm{FeO}^{\mathrm{b}}$ & 10.04 & 0.21 & 9.08 & 0.22 & 10.41 & 0.12 & 9.71 & 0.50 & 9.72 & 0.24 & 9.32 & 0.22 \\
\hline $\mathrm{MnO}^{\mathrm{b}}$ & 0.18 & 0.09 & 0.17 & 0.05 & 0.17 & 0.07 & 0.16 & 0.10 & 0.19 & 0.05 & 0.17 & 0.06 \\
\hline $\mathrm{MgO}^{\mathrm{b}}$ & 6.16 & 0.07 & 6.08 & 0.08 & 6.02 & 0.11 & 6.09 & 0.05 & 6.02 & 0.10 & 5.99 & 0.06 \\
\hline $\mathrm{CaO}^{\mathrm{b}}$ & 10.32 & 0.16 & 10.13 & 0.13 & 10.11 & 0.16 & 10.08 & 0.13 & 10.11 & 0.14 & 10.19 & 0.19 \\
\hline $\mathrm{Na}_{2} \mathrm{O}^{\mathrm{b}}$ & 3.25 & 0.07 & 3.38 & 0.09 & 3.20 & 0.10 & 3.13 & 0.09 & 3.16 & 0.15 & 3.24 & 0.10 \\
\hline $\mathrm{K}_{2} \mathrm{O}^{\mathrm{b}}$ & 1.85 & 0.06 & 1.96 & 0.05 & 1.82 & 0.10 & 1.85 & 0.07 & 1.81 & 0.09 & 1.87 & 0.09 \\
\hline Total & 97.34 & & 97.11 & & 96.58 & & 96.16 & & 95.73 & & 95.93 & \\
\hline $\mathrm{D} / \mathrm{H}^{\mathrm{c}}$ & -177.73 & 0.68 & -177.73 & 0.68 & -181.48 & 1.24 & -181.48 & 1.24 & -158.28 & 7.64 & -158.28 & 7.64 \\
\hline $\mathrm{H}_{2} \mathrm{O}^{\mathrm{d}}$ & 1.27 & & 1.27 & & 1.75 & & 1.75 & & 2.41 & & 2.41 & \\
\hline
\end{tabular}

${ }^{\mathrm{a}}$ The Etna glass standards were synthesized at ISTO (France). The starting material was an anhydrous glass obtained by melting a lava sample from Mt Etna. $800 \mathrm{mg}$ of the powdered anhydrous glass were loaded in sealed AuPd capsules with distilled water and equilibrated were equilibrated at 1500 bars and $1180-1200^{\circ} \mathrm{C}$, during $6 \mathrm{~h}$.

${ }^{\mathrm{b}}$ Major elements were analyzed using a SX50 microprobe (CAMPARIS, Jussieu, France) with a beam current of 10 nA. For each experimental charge, two fragments were analyzed. Each given analysis is the average of 7 analyzed points per fragment and is given with the standard deviation (SD).

${ }^{\mathrm{c}}$ The $\mathrm{D} / \mathrm{H}$ ratios were measured on $150 \mathrm{mg}$ bulk sample using mass spectrometry at CRPG.

${ }^{\mathrm{d}}$ The total water concentrations were determined on bulk samples, with a relative error of 5\%, using Karl Fisher Titration (KFT) at ISTO (France).

$7.6 \mathrm{ppm} ; \delta^{7} \mathrm{Li}=+10 \%$ ) and highly altered $\mathrm{AOC}$ $\left(\mathrm{Li}=33.1 \mathrm{ppm} ; \delta^{7} \mathrm{Li}=+11.8 \%\right)$. At high degrees of metamorphic dehydration $\left(667^{\circ} \mathrm{C}, 2.64 \mathrm{GPa}\right)$, fluids are estimated to have high Li contents from 65 to $283 \mathrm{ppm}$, depending on the degree of alteration of the crust, and high $\delta^{7} \mathrm{Li}$ (from +10.6 to $+12.4 \%$ ). In Grenada MIs, for which the B-systematics indicate the addition of a AOC derived fluid, $\mathrm{Li}$ increases from 3 to $17 \mathrm{ppm}$ and $\delta^{7} \mathrm{Li}$ decreases from +8 to $-4 \%$; (e.g., MIs G05-19 and G05-46a; Table 2). These relatively low $\delta^{7} \mathrm{Li}$ values do not fit the model of Marschall et al. [2007a]. On the other hand, most MIs with $\mathrm{B}$ and $\delta^{11} \mathrm{~B}$ imprint of sediment fluids show limited $\mathrm{Li}$ variations $(\mathrm{Li}<7 \mathrm{ppm})$ but a large $\delta^{7} \mathrm{Li}$ range (down to $-24 \%$; e.g., MIs
G05-5a, G05-69 and G05-109; Table 2). Following the Marschall et al. [2007a] modeling of AOC dehydration, these light $\delta^{7} \mathrm{Li}$ values are unlikely representative of dehydration fluids from Lesser Antilles sediments having $\delta^{7} \mathrm{Li}$ values from -1.7 to $+1.1 \%$ [Bouman et al., 2004]. Similarly, sediment-derived melts would have the same $\delta^{7} \mathrm{Li}$ than dehydrated sediment, as stable isotopes are not affected by high temperature magmatic processes [Tomascak et al., 1999]. In any case, the negative $\delta^{7} \mathrm{Li}$ cannot result from Li diffusion through the host olivine, because ${ }^{6} \mathrm{Li}$ diffuses faster than ${ }^{7} \mathrm{Li}$ [Lundstrom et al., 2005].

[44] We thus suggest that kinetic fractionation during dehydration of both $\mathrm{AOC}$ or sediments

Table A2 (Sample). Spinel Compositions ${ }^{\mathrm{a}}$ [The full Table A2 is available in the HTML version of this article]

\begin{tabular}{lccccccccc}
\hline & \multicolumn{7}{c}{ Spinels Isolated in Olivines } \\
\cline { 2 - 9 } & G05-06-25 & G05-06-25 & G05-07-13 & G05-07-13 & G05-07-13 & G05-07-41 & G05-07-41 & G05-07-40 & G05-07-40 \\
\hline $\mathrm{SiO}_{2}$ & 0.12 & 2.16 & 0.10 & 0.08 & 0.07 & 0.09 & 14.64 & 5.94 & 10.45 \\
$\mathrm{Al}_{2} \mathrm{O}_{3}$ & 21.1 & 19.2 & 27.6 & 27.2 & 20.4 & 20.8 & 12.3 & 16.6 & 17.3 \\
$\mathrm{MgO}$ & 13.0 & 14.2 & 13.3 & 13.3 & 13.1 & 12.2 & 17.3 & 12.1 & 8.8 \\
$\mathrm{TiO}_{2}$ & 0.42 & 0.47 & 1.49 & 1.41 & 0.85 & 0.60 & 1.28 & 0.97 & 1.33 \\
$\mathrm{Cr}_{2} \mathrm{O}_{3}$ & 42.3 & 39.6 & 23.6 & 24.4 & 31.4 & 39.5 & 21.7 & 33.1 & 27.3 \\
$\mathrm{MnO}$ & 0.28 & 0.24 & 0.20 & 0.22 & 0.24 & 0.33 & 0.39 & 0.35 & 0.35 \\
$\mathrm{FeO}$ & 23.0 & 24.5 & 31.4 & 31.4 & 32.1 & 25.9 & 32.7 & 34.8 & 34.5 \\
$\mathrm{Fe}_{2} \mathrm{O}_{3}$ & 12.6 & 13.9 & 22.3 & 22.0 & 20.1 & 14.6 & 24.1 & 21.6 & 22.8 \\
$\mathrm{Total}$ & 112.7 & 114.4 & 120.0 & 120.0 & 118.2 & 114.0 & 124.4 & 125.3 & 122.8 \\
$\mathrm{Mg \#}^{\text {b }}$ & 59.1 & 60.3 & 58.0 & 58.3 & 59.6 & 56.0 & 52.8 & 45.3 & 30.5 \\
$\mathrm{Cr}{ }^{c}$ & 57.4 & 58.1 & 36.4 & 37.6 & 50.9 & 56.0 & 54.2 & 57.2 & 51.5 \\
$\mathrm{Fo}^{\text {\% }}{ }^{\mathrm{d}}$ & 84.8 & 84.8 & 86.8 & 86.8 & 86.8 & 87.3 & 87.3 & 87.4 & 87.4 \\
\hline
\end{tabular}

${ }^{a}$ n.d. $=$ not determined.

${ }^{\mathrm{b}} \mathrm{Mg} \#=(100 * \mathrm{Mg}) /\left(\mathrm{Mg}+\mathrm{Fe}^{2+}\right)$ in spinel.

${ }^{\mathrm{c}} \mathrm{Cr} \#=(100 * \mathrm{Cr}) /(\mathrm{Cr}+\mathrm{Al})$.

${ }^{\mathrm{d}} \mathrm{Fo} \%=100 \times\left[\mathrm{Mg} /\left(\mathrm{Mg}+\mathrm{Fe}^{2+}\right)\right]$ in host olivine. 
Table A3. Summary of Values Used for the Boron Model ${ }^{\mathrm{a}}$

\begin{tabular}{lcc}
\hline & $\mathrm{B}(\mathrm{ppm})$ & $\delta^{11} \mathrm{~B}(\%)$ \\
\hline AOC & $17-40$ & $6-10$ \\
Average for calculations & 15.5 & 8 \\
Sediments & $11-120$ & -10 \\
Average for calculations & 47.0 & -10 \\
Serpentines & $0.3-120$ & $10-40.5$ \\
Average for calculations & 30.2 & 24 \\
Primitive mantle & 0.25 & -5.5 \\
$\mathrm{D}_{\mathrm{B}}^{\text {fluid/solid }}$ & 50 & \\
$\Delta_{\text {fluid-solid }}$ & & 5 \\
Fluids end-members & & \\
$\quad$ Serpentines (3\% dehydration) & 208 & 14 \\
$\quad$ AOC (2\% dehydration) & 506 & 4 \\
$\quad$ Sediments (5.5\% dehydration) & 81 & -32.5 \\
Dehydrated sediment & 2.2 & -35 \\
$\quad$ (5\% B loss) & &
\end{tabular}

\footnotetext{
${ }^{\mathrm{a}}$ Serpentines compositions are from Benton et al. [2001], Savov et al. [2005], and Vils et al. [2009]. Lesser Antilles sediment B contents are from this study (Table A4), whereas $\delta^{11} \mathrm{~B}$ are from Smith et al. [1997]. Boron compositions of DMM and AOC are from Chaussidon and Marty [1995] and Chaussidon and Libourel [1993], Chaussidon and Jambon [1994], and Spivack and Edmond [1987], respectively.
}

could strongly control the Li isotopic composition of Grenada MIs, whereas the boron model is based on isotopic equilibrium dehydration. This difference relies on the slower diffusivity of B compared to Li [Chakraborty et al., 1993].

\section{Conclusions}

[45] Direct ascent of magma through crustal fractures at Grenada has brought to the surface olivines hosting MIs with highly variable $\mathrm{H}_{2} \mathrm{O}, \mathrm{B}$, Li concentrations and $\delta^{11} \mathrm{~B}$ and $\delta^{7} \mathrm{Li}$ signatures. The water contents of these MIs vary from 0.2 to $6.4 \mathrm{wt} \%$, without correlation with the host olivine Fo content. Post-entrapment evolution of MIs involving hydrogen diffusion through olivine and magma degassing $\left(>90 \% \mathrm{H}_{2} \mathrm{O}\right.$ loss) caused by $\mathrm{CO}_{2}$-fluxing are excluded as the dominant processes producing the range in $\mathrm{H}_{2} \mathrm{O}$ content of the Grenada MIs. We propose that Grenada high $\mathrm{Mg}$-content, silica undersaturated magmas had variable $\mathrm{H}_{2} \mathrm{O}$ contents, although the lowest measured concentrations are believed to be non representative of the melt bat- ches. Grenada MIs are also characterized by low $\delta$ D (down to $-202 \%$ ), which are possibly ascribed to the influence of dehydration slab fluids with low $\delta \mathrm{D}$ values.

[46] The variability in $\mathrm{B}$ and $\delta^{11} \mathrm{~B}$ recorded by MIs requires the contributions of different slab derived fluids to the MORB-type mantle source:

[47] 1. Fluids $\left(\mathrm{B}=208 \mathrm{ppm}, \delta^{11} \mathrm{~B}=14 \%\right.$ ) derived from the dehydration of serpentinized peridotites formed above the slab beneath Grenada. This conclusion is supported by the overall $\mathrm{Cl}$-enrichment of Grenada MIs, whereas Li is not or only very slightly affected because of the low Li contents of fluids derived from serpentinite dehydration.

[48] 2. Fluids, having $506 \mathrm{ppm}$ of $\mathrm{B}$ and $\delta^{11} \mathrm{~B}$ value of $4 \%$, generated during the dehydration of the subducted AOC.

[49] 3. Fluids derived from sediments $(B=81 \mathrm{ppm}$; $\delta^{11} \mathrm{~B}=-32.5 \%$ ). The sediment-derived fluids are either aqueous fluids, or hydrous melt. The distinction between the two is difficult since little information is available for B isotopic fractionation in high temperature solute-rich aqueous fluids. The $\mathrm{Li}$ and $\delta^{7} \mathrm{Li}$ results suggest dehydration under conditions of Li-isotopic disequilibrium between fluid and residual solid, leading to light $\delta^{7} \mathrm{Li}$ fluid compositions. This is in contrast with the B-systematics, which could have been in equilibrium with the rock because of its lower diffusivity.

[50] The silica-undersaturated nature of the melts, and their enclosure in high Fo olivine (up to $\mathrm{Fo}_{91.8}$ ), indicate that these interactions took place at depth, in the upper mantle. The melts then ascended rapidly, probably due to the major bounding fault crossing Grenada.

\section{Appendix A}

[51] Table A1 shows the major elements compositions, $\mathrm{D} / \mathrm{H}$ ratios and water contents of Etna waterbearing synthetic glass standards, used for the calibration of ion microprobe measurements of $\mathrm{H}_{2} \mathrm{O}$ and $\mathrm{D} / \mathrm{H}$ in Grenada melt inclusions. Table A2

Table A4. Li and B Compositions of Lesser Antilles Sediments, DSDP Sites 144 and $543^{\mathrm{a}}$

\begin{tabular}{lccccccccccccc}
\hline & $543-5$ & $543-11$ & $543-19$ & $543-22$ & $543-24$ & $144-2$ & $144-15$ & $144-22$ & $144-24$ & $144-26$ & $144-29$ & $144-34$ & $144-36$ \\
\hline $\mathrm{Li}(\mathrm{ppm})$ & 72.6 & 46.80 & 60.60 & 39.1 & 21.5 & 15.6 & 11.9 & 32.3 & 1.44 & 10.4 & 6.96 & 58.4 & 24.8 \\
$\mathrm{~B}(\mathrm{ppm})$ & 120 & 66 & 109 & 92 & 68 & 60 & 56 & 66 & 11 & 52 & 41 & 65 & 22 \\
\hline
\end{tabular}

${ }^{a} \mathrm{Li}$ compositions are measured by M. Carpentier at LGCA (Grenoble, France), using ICP-MS [Carpentier et al., 2009]. B compositions are measured at SARM CRPG (Nancy, France), using MC-ICP-MS. Sediments 144-2 to 144-22 are carbonates, 144-24 and 144-29 are black shales, 144-34 and 36 are HFSE-enriched sandstone. Sediments from Site 543 are siliceous. Leg DSDP 144 have been realized in the South of the Lesser Antilles arc, whereas leg DSDP 543 is located in the North of the arc [Carpentier et al., 2008]. 
presents the major elements compositions of spinels either isolated in olivines or associated with olivine-hosted melt inclusions. The summary of values used for the boron model is reported in Table A3. Finally, Table A4 reports Li and B contents of the Lesser Antilles sediments (DSDP Sites 144 and 543). B compositions are from this study, determined at SARM CRPG (Nancy, France), whereas Li contents are from Carpentier et al. [2009].

\section{Acknowledgments}

[52] We are grateful to L. Cottrell, and an anonymous reviewer for their detailed comments and the Editor V. Salters for his constructive criticisms which greatly help to clarify the manuscript, F. Faure and L. Reisberg for constructive discussions, B. Scaillet for having synthesized the water-bearing basalt standards. For technical assistance, we thank D. Mangin and C. Rollion-Blard for measurements on the Cameca IMS 1270 and $3 \mathrm{f}$, and $\mathrm{O}$. Belhadj for sample preparation. This study was funded by CNRS- INSU DyETI and ANR-2005-UD-Antilles.

\section{References}

Anderson, A. T. (1974), Chlorine, sulfur, and water in magmas and oceans, Geol. Soc. Am. Bull., 85, 1485-1492, doi:10.1130/ 0016-7606(1974)85<1485:CSAWIM>2.0.CO;2.

Arculus, R. J. (1976), Geology and geochemistry of the alkali baslat-andesite association of Grenada, Lesser Antilles island arc, Geol. Soc. Am. Bull., 87, 612-624, doi:10.1130/ 0016-7606(1976)87<612:GAGOTA >2.0.CO;2.

Benton, L. D., J. G. Ryan, and F. Tera (2001), Boron isotope systematics of slab fluids as inferred from a serpentine seamount, Mariana forearc, Earth Planet. Sci. Lett., 187(3-4), 273-282, doi:10.1016/S0012-821X(01)00286-2.

Benton, L. D., J. G. Ryan, and I. P. Savov (2004), Lithium abundance and isotope systematics of forearc serpentinites, Conical Seamount, Mariana forearc: Insights into the mechanics of slab-mantle exchange during subduction, Geochem. Geophys. Geosyst., 5, Q08J12, doi:10.1029/ 2004GC000708.

Bonatti, E., and P. J. Michael (1989), Mantle peridotites from continental rifts to ocean basins to subductions zones, Earth Planet. Sci. Lett., 91(3-4), 297-311, doi:10.1016/0012821X(89)90005-8.

Bouman, C., T. Elliott, and P. Z. Vroon (2004), Lithium inputs to subduction zones, Chem. Geol., 212, 59-79, doi:10.1016/ j.chemgeo.2004.08.004.

Bouvier, A.-S., N. Métrich, and E. Deloule (2008), Slabderived fluids in magma sources of St. Vincent (Lesser Antilles Arc): Volatile and light element imprints, J. Petrol., 49, 1427-1448, doi:10.1093/petrology/egn031.

Carpentier, M., C. Chauvel, and N. Mattielli (2008), Pb-Nd isotopic constraints on sedimentary input into the Lesser Antilles arc system, Earth Planet. Sci. Lett., 272, 199211, doi:10.1016/j.epsl.2008.04.036.

Carpentier, M., C. Chauvel, R. C. Maury, and N. Mattielli (2009), The "zircon effect" as recorded by the chemical and Hf isotopic compositions of Lesser Antilles forearc sediments, Earth. Planet. Sci. Lett., 287(1-2), 86-99.
Carroll, M. R., and P. J. Wyllie (1989), Experimental phase relations in the system tonalite-peridotite- $\mathrm{H}_{2} \mathrm{O}$ at $15 \mathrm{~kb}$ : Implications for assimilation and differentiation processes near the crust-mantle boundary, J. Petrol., 30(6), 13511382.

Cervantes, P., and P. J. Wallace (2003), Role of $\mathrm{H}_{2} \mathrm{O}$ in subduction-zone magmatism: New insights from melt inclusions in high-Mg basalts from central Mexico, Geology, 31(3), 235-238, doi:10.1130/0091-7613(2003)031<0235: ROHOIS $>2.0 . \mathrm{CO} ; 2$.

Chakraborty, S. (1997), Rates and mechanisms of $\mathrm{Fe}-\mathrm{Mg}$ interdiffusion in olivine at $980-1300^{\circ} \mathrm{C}, J$. Geophys. Res., 102(B6), 12,317-12,331, doi:10.1029/97JB00208.

Chakraborty, S., D. B. Dingwell, and M. Chaussidon (1993), Chemical diffusivity of boron in melts of haplogranitic composition, Geochim. Cosmochim. Acta, 57(8), 1741-1751, doi:10.1016/0016-7037(93)90110-I.

Chan, L.-H., and M. Kastner (2000), Lithium isotopic compositions of pore fluids and sediments in the Costa Rica subduction zone: Implications for fluid processes and sediment contribution to the arc volcanoes, Earth Planet. Sci. Lett., 183(1-2), 275-290, doi:10.1016/S0012-821X(00)00275-2.

Chan, L.-H., J. M. Edmond, G. Thompson, and K. Gillis (1992), Lithium isotopic composition of submarine basalts: Implications for the lithium cycle in the oceans, Earth Planet. Sci. Lett., 108, 151-160, doi:10.1016/0012-821X (92)90067-6.

Chan, L.-H., J. M. Edmond, and G. Thompson (1993), A lithium isotope study of hot springs and metabasalts from mid-ocean ridge hydrothermal systems, J. Geophys. Res., 98(B6), 9653-9659, doi:10.1029/92JB00840.

Chan, L.-H., J. M. Gieskes, Y. Chen-Feng, and J. M. Edmond (1994), Lithium isotope geochemistry of sediments and hydrothermal fluids of the Guaymas Basin, Gulf of California, Geochim. Cosmochim. Acta, 58(20), 4443-4454, doi:10.1016/0016-7037(94)90346-8.

Chaussidon, M., and A. Jambon (1994), Boron content and isotopic composition of oceanic basalts: Geochemical and cosmochemical implications, Earth Planet. Sci. Lett., 121, 277-291, doi:10.1016/0012-821X(94)90073-6.

Chaussidon, M., and G. Libourel (1993), Boron partitioning in the upper mantle: An experimental and ion probe study, Geochim. Cosmochim. Acta, 57, 5053-5062, doi:10.1016/ 0016-7037(93)90607-X.

Chaussidon, M., and B. Marty (1995), Primitive boron isotope composition of the mantle, Science, 269, 383-386, doi:10.1126/science.269.5222.383.

Chaussidon, M., S. M. F. Sheppard, and A. Michard (1991), Hydrogen, sulphur and neodymium isotope variations in the mantle beneath the EPR at $12^{\circ} 50^{\prime} \mathrm{N}$, in Stable Isotope Geochemistry: A Tribute to Samuel Epstein, edited by H. P. Taylor, J. R. O’Neil, and I. R. Kaplan, pp. 325-337, Geochem. Soc., San Antonio, Tex.

Craig, H., and J. E. Lupton (1976), Primordial, helium and hydrogen in oceanic basalts, Earth Planet. Sci. Lett., 31, 369-385, doi:10.1016/0012-821X(76)90118-7.

Danyushevsky, L. V., F. N. Della-Pasqua, and S. Sokolov (2000), Re-equilibration of melt inclusions trapped by magnesian olivine phenocrysts from subduction-related magmas: Petrological implications, Contrib. Mineral. Petrol., 138(1), 68-83, doi:10.1007/PL00007664.

Danyushevsky, L. V., S. Sokolov, and T. J. Falloon (2002a), Melt inclusions in olivine phenocrysts: Using diffusive re-equilibration to determine the cooling history of a crystal, with implications for the origin of olivine-phyric volcanic 
rocks, J. Petrol., 43(9), 1651-1671, doi:10.1093/petrology/ 43.9.1651.

Danyushevsky, L. V., A. W. McNeill, and A. V. Sobolev (2002b), Experimental and petrological studies of melt inclusions in phenocrysts from mantle-derived magmas: An overview of techniques, advantages and complications, Chem. Geol., 183(1-4), 5-24, doi:10.1016/S0009-2541(01) 00369-2.

Decitre, S., E. Deloule, L. Reisberg, R. H. James, P. Agrinier, and C. Mével (2002), Behavior of $\mathrm{Li}$ and its isotopes during serpentinization of oceanic peridotites, Geochem. Geophys. Geosyst., 3(1), 1007, doi:10.1029/2001GC000178.

De Hoog, J. C. M., B. E. Taylor, and M. J. Van Bergen (2009), Hydrogen-isotope systematics in degassing basaltic magma and application to Indonesian arc basalts, Chem. Geol., 266(3-4), 256-266, doi:10.1016/j.chemgeo.2009.06.010.

Deloule, E., F. Albarède, and S. M. F. Sheppard (1991), Hydrogen isotope heterogeneities in the mantle from ion probe analysis of amphiboles from ultramafic rocks, Earth Planet. Sci. Lett., 105, 543-553, doi:10.1016/0012-821X (91)90191-J.

Devine, J. D. (1995), Petrogenesis of the basalt-andesite-dacite association of Grenada, Lesser Antilles island arc, revisited, J. Volcanol. Geotherm. Res., 69, 1-33, doi:10.1016/03770273(95)00024-0.

Gaetani, G. A., J. A. O'Leary, and N. Shimizu (2009), Mechanisms and timescales for reequilibration of water in olivine-hosted melt inclusions, Eos Trans. AGU, 90(52), Fall Meet. Suppl., Abstract V51E-1770.

Hauri, E. (2002), SIMS analysis of volatiles in silicate glasses, 2: Isotopes and abundances in Hawaiian melt inclusions, Chem. Geol., 183, 115-141, doi:10.1016/S0009-2541(01) 00374-6.

Hawkesworth, C. J., R. K. O’Nions, and R. J. Arculus (1979), $\mathrm{Nd}$ and $\mathrm{Sr}$ isotope geochemistry of island arc volcanics, Grenada, Lesser Antilles, Earth Planet. Sci. Lett., 45, 237248, doi:10.1016/0012-821X(79)90126-2.

Heath, E., R. MacDonald, H. Belkin, C. Hawkesworth, and H. Sigurdsson (1998), Magmagenesis at Soufriere Volcano, St Vincent, Lesser Antilles Arc, J. Petrol., 39(10), 17211764, doi:10.1093/petrology/39.10.1721.

Hirose, K., and I. Kushiro (1993), Partial melting of dry peridotites at high pressures: Determination of compositions of melts segregated from peridotite using aggregated of diamond, Earth Planet. Sci. Lett., 114(4), 477-489, doi:10.1016/0012-821X(93)90077-M.

Holzheid, A., and T. L. Grove (2002), Sulfur saturation limits in silicate melts and their implications for core formation scenarios for terrestrial planets, Am. Mineral., 87(2-3), 227-237.

Huh, Y., L.-H. Chan, and J. M. Edmond (2001), Lithium isotopes as a probe of weathering processes: Orinoco River, Earth Planet. Sci. Lett., 194(1-2), 189-199, doi:10.1016/ S0012-821X(01)00523-4.

Ishikawa, T., and E. Nakamura (1993), Boron isotope systematics of marine sediments, Earth Planet. Sci. Lett., 117(3-4), 567-580, doi:10.1016/0012-821X(93)90103-G.

Johnson, E. R., P. J. Wallace, K. V. Cashman, H. D. Granados, and A. J. R. Kent (2008), Magmatic volatile contents and degassing-induced crystallization at Volcán Jorullo, Mexico: Implications for melt evolution and the plumbing systems of monogenetic volcanoes, Earth Planet. Sci. Lett., 269(3-4), 478-487, doi:10.1016/j.eps1.2008.03.004.

Johnson, E. R., P. J. Wallace, K. V. Cashman, and H. D. Granados (2010), Degassing of volatiles $\left(\mathrm{H}_{2} \mathrm{O}, \mathrm{CO}_{2}, \mathrm{~S}, \mathrm{Cl}\right)$ during ascent, crystallization, and eruption at mafic monogenetic volcanoes in central Mexico, J. Volcanol. Geotherm. Res., in press.

Johnson, M. C., and T. Plank (1999), Dehydration and melting experiments constrain the fate of subducted sediments, Geochem. Geophys. Geosyst., 1(12), 1007, doi:10.1029/ 1999GC000014.

Kamenetsky, V. S., M. Elburg, R. Arculus, and R. Thomas (2006), Magmatic origin of low-Ca olivine in subductionrelated magmas: Co-existence of contrasting magmas, Chem. Geol., 233(3-4), 346-357, doi:10.1016/j.chemgeo. 2006.03.010

Kohut, E. J., R. J. Stern, A. J. R. Kent, R. L. Nielsen, S. H. Bloomer, and M. Leybourne (2006), Evidence for adiabatic decompression melting in the Southern Mariana Arc from high-Mg lavas and melt inclusions, Contrib. Mineral. Petrol., 152(2), 201-221, doi:10.1007/s00410-006-0102-7.

Kuzmin, D. V., and A. V. Sobolev (2003), Boundary layer effect on the composition of melt inclusions in olivine, Geophys. Res. Abstr., 5, 05665.

Kyser, T. K., and J. R. O’Neil (1984), Hydrogen isotope systematics of submarine basalts, Geochim. Cosmochim. Acta, 48, 2123-2133, doi:10.1016/0016-7037(84)90392-2.

Le Voyer, M., E. F. Rose-Koga, M. Laubier, and P. Schiano (2008), Petrogenesis of arc lavas from the Rucu Pichincha and Pan de Azucar volcanoes (Ecuadorian arc): Major, trace element, and boron isotope evidences from olivine-hosted melt inclusions, Geochem. Geophys. Geosyst., 9, Q12027, doi:10.1029/2008GC002173.

Le Voyer, M., E. F. Rose-Koga, N. Shimizu, T. L. Grove, and P. Schiano (2010), Two contrasting $\mathrm{H}_{2} \mathrm{O}$-rich components in primary melt inclusions from Mount Shasta, J. Petrol., 51(7), 1571-1595, doi:10.1093/petrology/egq030.

Lundstrom, C. C., M. Chaussidon, A. T. Hsui, P. Kelemen, and M. Zimmerman (2005), Observations of Li isotopic variations in the Trinity Ophiolote: Evidence for isotopic fractionation by diffusion during mantle melting, Geochim. Cosmochim. Acta, 69(3), 735-751, doi:10.1016/j.gca.2004. 08.004 .

Macdonald, R., C. J. Hawkesworth, and E. Heath (2000), The Lesser Antilles volcanic chain: A study in arc magmatism, Earth Sci. Rev., 49, 1-76, doi:10.1016/S0012-8252(99) 00069-0.

Mackwell, S. J., and D. L. Kohlstedt (1990), Diffusion of hydrogen in olivine: Implication for water in the mantle, J. Geophys. Res., 95, 5079-5088, doi:10.1029/ JB095iB04p05079.

Marschall, H., P. A. E. Pogge von Strandmann, H.-M. Seitz, T. Elliott, and Y. Niu (2007a), The lithium isotopic composition of orogenic eclogites and deep subducted slabs, Earth Planet. Sci. Lett., 262(3-4), 563-580, doi:10.1016/j. epsl.2007.08.005.

Marschall, H. R., R. Altherr, and L. Rüpke (2007b), Squeezing out the slab-Modelling the release of $\mathrm{Li}, \mathrm{Be}$ and $\mathrm{B}$ during progressive high-pressure metamorphism, Chem. Geol., 239(3-4), 323-335, doi:10.1016/j.chemgeo.2006.08.008.

Michael, P. J. (1995), Regionally distinctive sources of depleted MORB: Evidence from trace elements and $\mathrm{H}_{2} \mathrm{O}$, Earth Planet. Sci. Lett., 131(3-4), 301-320, doi:10.1016/ 0012-821X(95)00023-6.

Newman, S., and J. B. Lowenstern (2002), VC: A silicate melt- $\mathrm{H}_{2} \mathrm{O}-\mathrm{CO}_{2}$ solution model written in Visual Basic for Excel, Comput. Geosci., 28(5), 597-604, doi:10.1016/ S0098-3004(01)00081-4. 
Newman, S., S. Epstein, and E. Stolper (1988), Water, carbon dioxide, and hydrogen isotopes in glasses from the ca. 1340 A.D. eruption of the Mono Craters, California: Constraints on degassing phenomena and initial volatile content, J. Volcanol. Geotherm. Res., 35(1-2), 75-96, doi:10.1016/ 0377-0273(88)90007-8.

Parkinson, I. J., R. J. Arculus, and S. M. Eggins (2003), Peridotite xenoliths from Grenada, Lesser Antilles Island Arc, Contrib. Mineral. Petrol., 146, 241-262, doi:10.1007/ s00410-003-0500-z.

Peacock, S. M., and R. L. Hervig (1999), Boron isotopic composition of subduction-zone metamorphic rocks, Chem. Geol., 160(4), 281-290, doi:10.1016/S0009-2541(99) 00103-5.

Pichavant, M., and R. MacDonald (2003), Mantle genesis and crustal evolution of primitive calc-alkaline basaltic magmas from the Lesser Antilles arc, Geol. Soc. Spec. Publ., 219, 239-254.

Pichavant, M., B. O. Mysen, and R. MacDonald (2002), Source and $\mathrm{H}_{2} \mathrm{O}$ contents of high- $\mathrm{MgO}$ magmas in island arc settings: An experimental study of a primitive calcalkaline basalt from St-Vincent, Lesser Antilles arc, Geochim. Cosmochim. Acta, 66(12), 2193-2209, doi:10.1016/S00167037(01)00891-2.

Pineau, F., and M. Javoy (1994), Strong degassing at ridge crests: The behaviour of dissolved carbon and water in basalt glasses at $14^{\circ} \mathrm{N}$, Mid-Atlantic Ridge, Earth Planet. Sci. Lett., 123(1-3), 179-198, doi:10.1016/0012-821X(94)90266-6.

Plank, T., J. N. Ludden, and C. Escutia (2000), Proceedings of the Ocean Drilling Program, Initial Reports, vol. 185, Ocean Drill. Program, College Station, Tex.

Portnyagin, M., R. Almeev, S. Matveev, and F. Holtz (2008), Experimental evidence for rapid water exchange between melt inclusions in olivine and host magma, Earth Planet. Sci. Lett., 272, 541-552, doi:10.1016/j.epsl.2008.05.020.

Poussineau, S. (2005), Dynamique des magmas andésitiques: Approches expérimentales et pétrostructurale; application à la Souffrière de Guadeloupe et à la Montagne Pelée, Ph.D. thesis, 300 pp., Univ, d'Orléans, Orléans, France.

Rose, E. F., N. Shimizu, G. D. Layne, and T. L. Grove (2001), Melt production beneath Mt. Shasta from Boron data in primitive melt inclusions, Science, 293, 281-283, doi:10.1126/ science. 1059663.

Rudnick, R. L., P. B. Tomascak, H. B. Njo, and L. R. Gardner (2004), Extreme lithium isotopic fractionation during continental weathering revealed in saprolites from South Carolina, Chem. Geol., 212, 45-57, doi:10.1016/j.chemgeo. 2004.08.008.

Ryan, J. G., and C. H. Langmuir (1993), The systematics of boron abundances in young volcanic rocks, Geochim. Cosmochim. Acta, 57(7), 1489-1498, doi:10.1016/0016-7037 (93)90008-K.

Saal, A. E., E. H. Hauri, C. H. Langmuir, and M. R. Perfit (2002), Vapour undersaturation in primitive mid-oceanridge basalt and the volatile content of Earth's upper mantle, Nature, 419(6906), 451-455, doi:10.1038/nature01073.

Savov, I. P., J. G. Ryan, M. D'Antonio, K. Kelley, and P. Mattie (2005), Geochemistry of serpentinized peridotites from the Mariana Forearc Conical Seamount, ODP Leg 125: Implications for the elemental recycling at subduction zones, Geochem. Geophys. Geosyst., 6, Q04J15, doi:10.1029/ $2004 \mathrm{GC} 000777$.

Scambelluri, M., O. Müntener, L. Ottolini, T. T. Pettke, and R. Vannucci (2004), The fate of B, Cl and $\mathrm{Li}$ in the subducted oceanic mantle and in the antigorite breakdown fluids, Earth Planet. Sci. Lett., 222(1), 217-234, doi:10.1016/j.eps1.2004.02.012.

Shaw, A. M., E. H. Hauri, T. P. Fischer, D. R. Hilton, and K. A. Kelley (2008), Hydrogen isotopes in Mariana arc melt inclusions: Implications for subduction dehydration and the deep-Earth water cycle, Earth Planet. Sci. Lett., 275(1-2), 138-145, doi:10.1016/j.epsl.2008.08.015.

Sheppard, S. M. F., and J. B. Dawson $(1973),{ }^{13} \mathrm{C} /{ }^{12} \mathrm{C}$ and D/H isotope variations in primary igneous carbonatites, Fortschr. Mineral., 50, 128-129.

Sisson, T. W., and S. Bronto (1998), Evidence for pressurerelease melting beneath magmatic arcs from basalt at Galunggung, Indonesia, Nature, 391(6670), 883-886, doi:10.1038/ 36087.

Sisson, T. W., and T. L. Grove (1993), Experimental investigations of the role of $\mathrm{H}_{2} \mathrm{O}$ in calc-alkaline differentiation and subduction zone magmatism, Contrib. Mineral. Petrol., 113(2), 143-166, doi:10.1007/BF00283225.

Sisson, T. W., and G. D. Layne (1993), $\mathrm{H}_{2} \mathrm{O}$ in basalt and basaltic andesite glass inclusions from four subductionrelated volcanoes, Earth Planet. Sci. Lett., 117(3-4), 619635, doi:10.1016/0012-821X(93)90107-K.

Smith, H. J., W. P. Leeman, J. Davidson, and A. J. Spivack (1997), The B isotopic composition of arc lavas from Martinique, Lesser Antilles, Earth Planet. Sci. Lett., 146, $303-$ 314, doi:10.1016/S0012-821X(96)00209-9.

Sobolev, A. V., and N. Shimizu (1993), Ultradepleted primary melt included in olivine from the Mid-Atlantic Ridge, Nature, 363, 151-154, doi:10.1038/363151a0.

Spilliaert, N., N. Métrich, and P. Allard (2006), S-Cl-F degassing pattern of water-rich alkali basalt: Modelling and relationship with eruption styles on Mount Etna volcano, Earth Planet. Sci. Lett., 248(3-4), 772-786, doi:10.1016/j. epsl.2006.06.031.

Spivack, A. J., and J. M. Edmond (1987), Boron isotope exchange between seawater and the oceanic crust, Geochim. Cosmochim. Acta, 51(5), 1033-1043, doi:10.1016/00167037(87)90198-0.

Stoffyn-Egli, P., and F. T. Mackenzie (1984), Mass balance of dissolved lithium in the oceans, Geochim. Cosmochim. Acta, 48, 859-872, doi:10.1016/0016-7037(84)90107-8.

Straub, S. M., and G. D. Layne (2003a), Decoupling of fluids and fluid-mobile elements during shallow subduction: Evidence from halogen-rich andesite melt inclusions from the Izu arc volcanic front, Geochem. Geophys. Geosyst., 4(7), 9004, doi:10.1029/2002GC000349.

Straub, S. M., and G. D. Layne (2003b), The systematics of chlorine, fluorine, and water in Izu arc front volcanic rocks: Implications for volatile recycling in subduction zone, Geochim. Cosmochim. Acta, 67(21), 4179-4203, doi:10.1016/S00167037(03)00307-7.

Suzuoki, T., and S. Epstein (1976), Hydrogen isotope fractionation between $\mathrm{OH}$-bearing minerals and water, Geochim. Cosmochim. Acta, 40, 1229-1240, doi:10.1016/0016-7037 (76)90158-7.

Teng, F.-Z., W. F. McDonough, R. L. Rudnick, C. Dalpé, P. B. W. Tomascak, and S. Gao (2004), Lithium isotopic composition and concentration of the upper continental crust, Geochim. Cosmochim. Acta, 68, 4167-4178, doi:10.1016/j. gca.2004.03.031.

Teng, F.-Z., W. F. McDonough, R. L. Rudnick, and B. A. Wing (2007), Limited lithium isotopic fractionation during progressive metamorphic dehydration in metapelites: A case study from the Onawa contact aureole, Maine, Chem. Geol., 239, 1-12, doi:10.1016/j.chemgeo.2006.12.003. 
Thirlwall, M. F., and A. M. Graham (1984), Evolution of high$\mathrm{Ca}$, high-Sr C-series basalts from Grenada Lesser Antilles: The effects of intra-crustal contamination, J. Geol. Soc., 141, 427-445, doi:10.1144/gsjgs.141.3.0427.

Thirlwall, M. F., T. E. Smith, A. M. Graham, N. Thodorou, P. Hollings, J. P. Davidson, and R. J. Arculus (1994), High field strength element anomalies in arc lavas: Source or process?, J. Petrol., 35(3), 819-838.

Thirlwall, M. F., A. M. Graham, R. J. Arculus, R. S. Harmon, and C. G. Macperson (1996), Resolution of the effects of crustal contamination, sediment subduction, and fluid transport in island arc magmas: $\mathrm{Pb}-\mathrm{Sr}-\mathrm{Nd}-\mathrm{O}$ isotope geochemistry of Grenada, Lesser Antilles, Geochim. Cosmochim. Acta, 60(23), 4785-4810, doi:10.1016/S0016-7037(96)00272-4.

Tomascak, P. B., F. Tera, R. T. Helz, and R. J. Walker (1999), The absence of lithium isotope fractionation during basalt differentiation: New measurements by multicollector sector ICP-MS Geochim. Cosmochim. Acta, 63(6), 907-910, doi:10.1016/S0016-7037(98)00318-4.

Tomascak, P. B., J. G. Ryan, and M. J. Defant (2000), Lithium isotope evidence for light element decoupling in the Panama subarc mantle, Geology, 28(6), 507-510, doi:10.1130/00917613(2000)28<507:LIEFLE $>2.0$. CO;2.

Tomascak, P. B., C. H. Langmuir, P. J. le Roux, and S. B. Shirey (2008), Lithium isotopes in global mid-ocean ridge basalts, Geochim. Cosmochim. Acta, 72(6), 1626-1637, doi:10.1016/j.gca.2007.12.021.

Toplis, M. J. (2005), The thermodynamics of iron and magnesium partitioning between olivine and liquid: Criteria for assessing and predicting equilibrium in natural experimental systems, Contrib. Mineral. Petrol., 149, 22-39, doi:10.1007/ s00410-004-0629-4.

Turner, S., C. Hawkesworth, P. Van Calsteren, E. Heath, R. MacDonald, and S. Black (1996), U-series isotopes and destructive plate margin magma genesis in the Lesser Antilles, Earth Planet. Sci. Lett., 142, 191-207, doi:10.1016/0012821X(96)00078-7.

Vannucci, R., M. Tieplo, M. J. Defant, and P. Kepezhinskas (2007), The metasomatic record in the shallow peridotite mantle beneath Grenada (Lesser Antilles arc), Lithos, 99, 25-44, doi:10.1016/j.lithos.2007.05.007.

Van Soest, M. C., D. R. Hilton, C. G. Macpherson, and D. P. Mattey (2002), Resolving sediments subduction and crustal contamination in the Lesser Antilles Island Arc: A combined He-O-Sr isotope approach, J. Petrol., 43(1), 143-170, doi:10.1093/petrology/43.1.143.

Vils, F., L. Pelletier, A. Kalt, O. Müntener, and T. Ludwig (2008), The lithium, boron and beryllium content of serpentinized peridotites from ODP Leg 209 (Sites 1272A and 1274A): Implications for lithium and boron budgets of oceanic lithosphere, Geochim. Cosmochim. Acta, 72(22), 5475-5504, doi:10.1016/j.gca.2008.08.005.

Vils, F., S. Tonarini, A. Kalt, and H.-M. Seitz (2009), Boron, lithium and strontium isotopes as tracers of seawaterserpentinite interaction at Mid-Atlantic ridge, ODP Leg 209, Earth Planet. Sci. Lett., 286(3-4), 414-425, doi:10.1016/j. eps1.2009.07.005.

Wallace, P. J. (2005), Volatiles in subduction zone magmas: Concentrations and fluxes based on melt inclusion and volcanic gas data, J. Volcanol. Geotherm. Res., 140, 217-240, doi:10.1016/j.jvolgeores.2004.07.023.

Wallace, P., and I. S. E. Carmichael (1992), Sulfur in basaltic magmas, Geochim. Cosmochim. Acta, 56, 1863-1874, doi:10.1016/0016-7037(92)90316-B.

White, W. M., and B. Dupré (1986), Sediment subduction and magma genesis in the Lesser Antilles: Isotopic and trace element constraints, J. Geophys. Res., 91, 5927-5941, doi:10.1029/JB091iB06p05927.

Woodland, S. J., D. G. Pearson, and M. F. Thirlwall (2002), A platinum group element and Re-Os isotope investigation of siderophile element recycling in subduction zone: Comparison of Grenada, Lesser Antilles Arc and the Izu-Bonin Arc, J. Petrol., 43(1), 171-198, doi:10.1093/petrology/43.1.171.

Wunder, B., A. Meixner, R. L. Romer, R. Wirth, and W. Heinrich (2005), The geochemical cycle of boron: Constraints from boron isotope partitioning experiments between mica and fluid, Lithos, 84(3-4), 206-216, doi:10.1016/j.lithos.2005. 02.003 .

Xia, Q. K., E. Deloule, D. G. Chen, Y. B. Wu, and H. Cheng (2002), Anomalously high $\delta \mathrm{D}$ values in the mantle, Geophys. Res. Lett., 29(21), 2008, doi:10.1029/2001GL013887.

Zhang, Y.-G., and J. D. Frantz (2000), Enstatite-forsteritewater equilibria at elevated temperatures and pressures, Am. Mineral., 85(7-8), 918-925. 